\title{
Prenylated Acylphloroglucinols from Hypericum faberi
}

Xin-Wen Zhang, Shao-Qiang Fan, Fan Xia, Yan-Song Ye, Xing-Wei Yang, Xian-Wen Yang, Gang Xu

\section{Supporting Information}

\section{Table of Contents}

- General experimental procedures (Page S2)

- Biological assay (Page S2-S3)

- Original MS and NMR spectra of compounds 1-6 (Page S4-S33) 


\section{General Experimental Procedures}

Optical rotations were measured on a JASCO P-1020 polarimeter. UV spectra were recorded on a Shimadzu UV-2401PC spectrometer. IR spectra were recorded on a Bruker FT-IR Tensor-27 infrared spectrophotometer with KBr disks. 1D and 2D NMR spectra were recorded on a Bruker DRX-600 spectrometer using TMS as an internal standard. The chemical shifts $(\delta)$ were expressed in ppm with reference to the solvent signals. ESIMS and HR-ESIMS analysis were carried out on Waters Xevo TQS and Agilent G6230 TOF mass spectrometers, respectively. Preparative and semipreparative HPLC were performed on Waters 1525 HPLC (column: SunFire OBD-C 18 , $19 \times 250 \mathrm{~mm}$ ) and Agilent 1100 HPLC (column: Zorbax SB-C $18,9.4 \times 250 \mathrm{~mm}$ ), respectively. Silica gel (100-200 and 200-300 mesh, Qingdao Marine Chemical Co., Ltd., People's Republic of China), and MCI gel (75-150 $\mu \mathrm{m}$, Mitsubishi Chemical Corporation, Tokyo, Japan) were used for column chromatography. Fractions were monitored by TLC (GF 254, Qingdao Marine Chemical Co., Ltd.), and spots were visualized by heating silica gel plates immersed in $\mathrm{H}_{2} \mathrm{SO}_{4}$ in ethanol.

\section{Biological assay}

Colorimetric assays were performed to evaluate compound activity. The following human tumor cell lines were used: ECA-109 esophageal cancer cell line, PANC-1 pancreatic cell line, BIU-87 bladder cancer cell line, and BEL-7402 hepatoma cell line. All cells were cultured in RPMI-1640 or DMEM medium (Hyclone, Logan, UT), supplemented with $10 \%$ fetal bovine serum (Hyclone) at $37{ }^{\circ} \mathrm{C}$ in a humidified atmosphere with $5 \% \mathrm{CO}_{2}$. Cell viability was assessed by conducting colorimetric measurements of the amount of insoluble formazan formed in living cells based on the reduction of 3-(4,5-dimethylthiazol-2-yl)-2,5-diphenyltetrazolium bromide (MTT). Briefly, $100 \mu \mathrm{L}$ adherent cells were seeded into each well of a 96-well cell culture plate and allowed to adhere for $12 \mathrm{~h}$ before test compound addition, while suspended cells were seeded just before this step, both with initial density of $1 \times 10^{5}$ cells $/ \mathrm{mL}$ in $100 \mu \mathrm{L}$ of medium. Each tumor cell line was exposed to the test compound at various 
concentrations in triplicate for $48 \mathrm{~h}$, with Taxol as positive control. After the incubation, MTT $(100 \mu \mathrm{g})$ was added to each well, and the incubation continued for $4 \mathrm{~h}$ at $37^{\circ} \mathrm{C}$. The cells were lysed with $100 \mu \mathrm{L}$ of $20 \%$ SDS-50\% DMF after removal of $100 \mu \mathrm{L}$ of medium. The optical density of the lysate was measured at $595 \mathrm{~nm}$ in a 96-well microtiter plate reader (Bio-Rad 680). The $\mathrm{IC}_{50}$ value of each compound was calculated by Reed and Muench's method. 


\section{Original MS and NMR spectra of compounds 1-6}

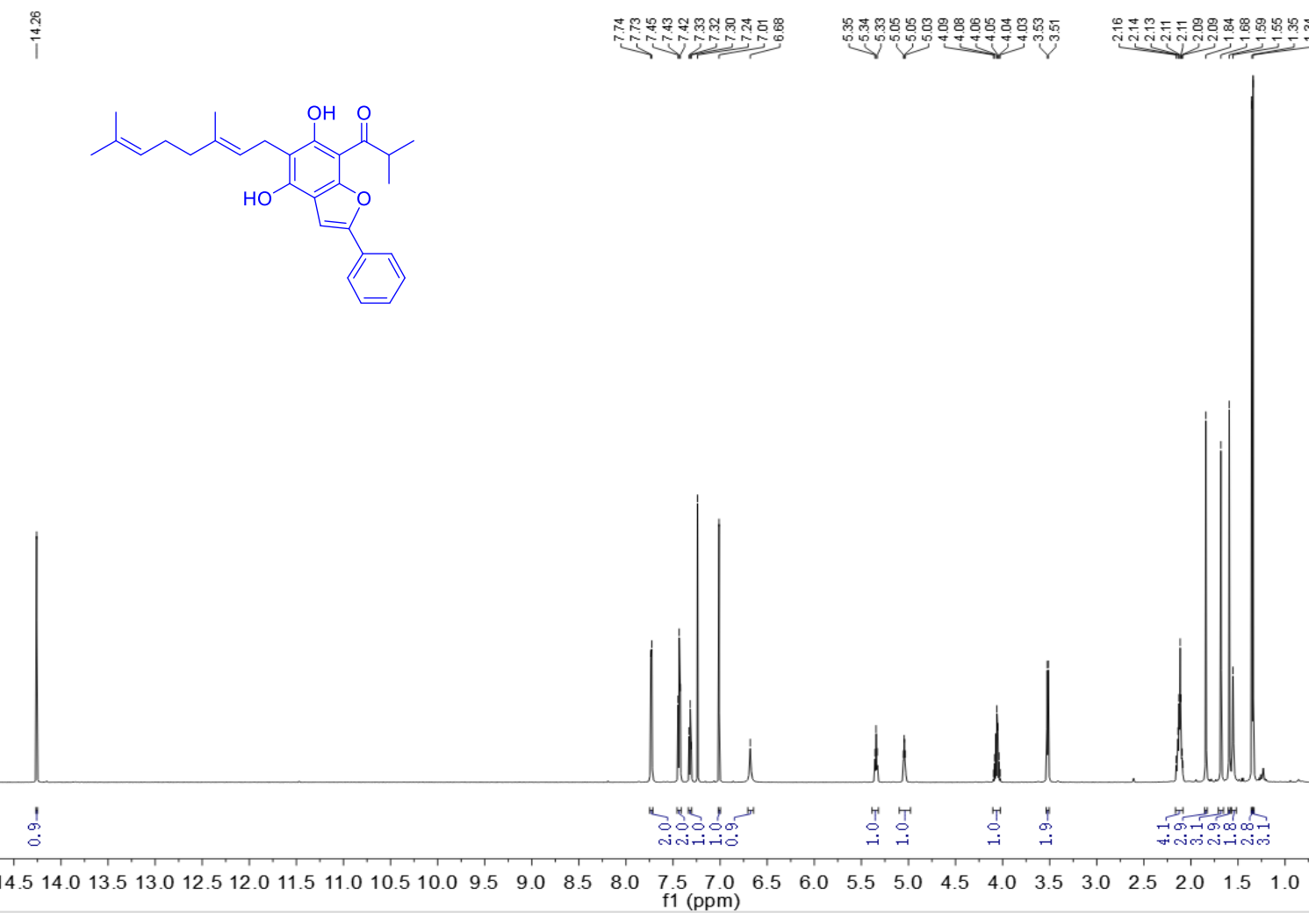

Figure S1. ${ }^{1} \mathrm{H}$ (in $\mathrm{CDCl}_{3}$ ) spectrum of $\mathbf{1}$.
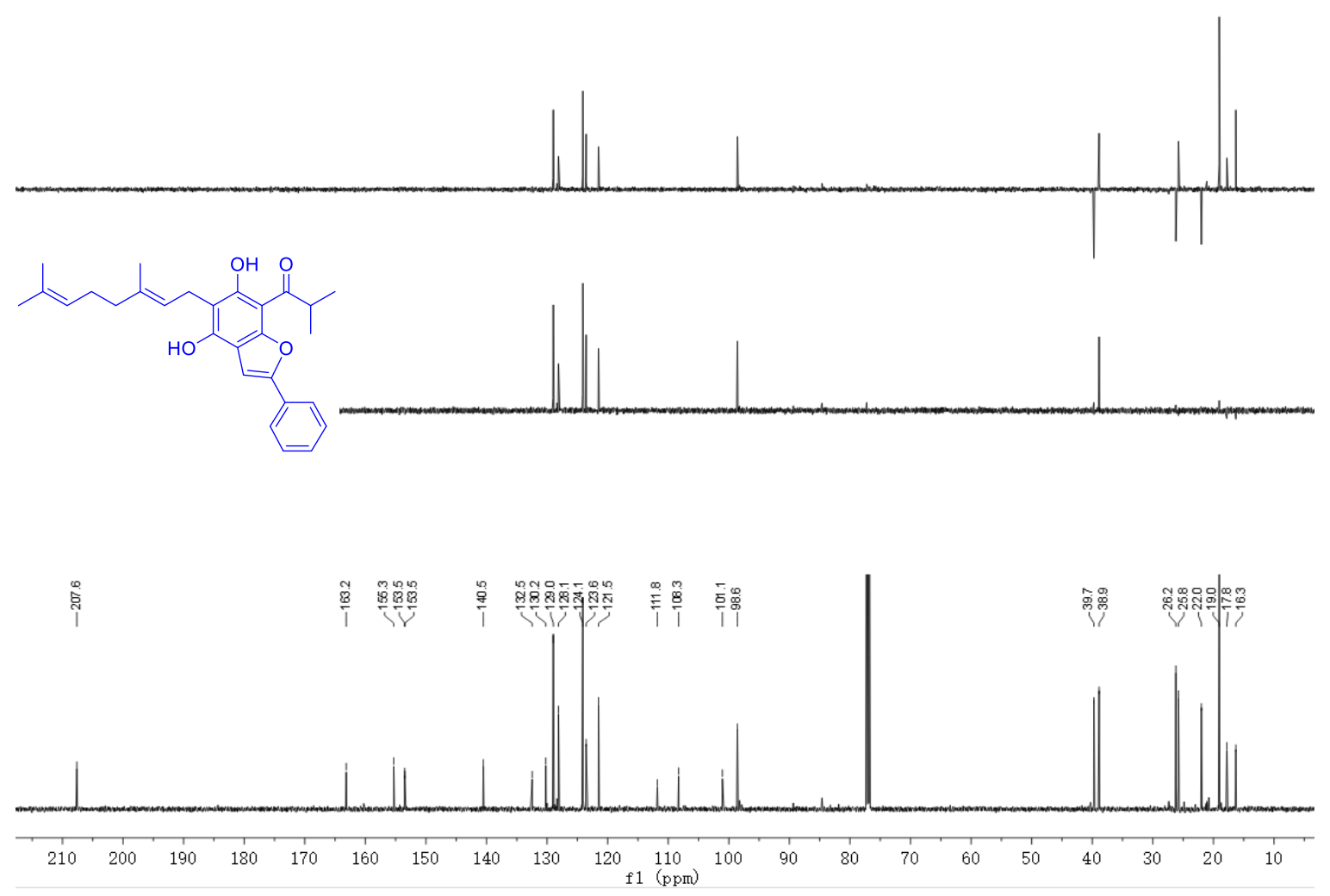

Figure S2. ${ }^{13} \mathrm{C}$ and DEPT (in $\mathrm{CDCl}_{3}$ ) spectrum of $\mathbf{1}$. 


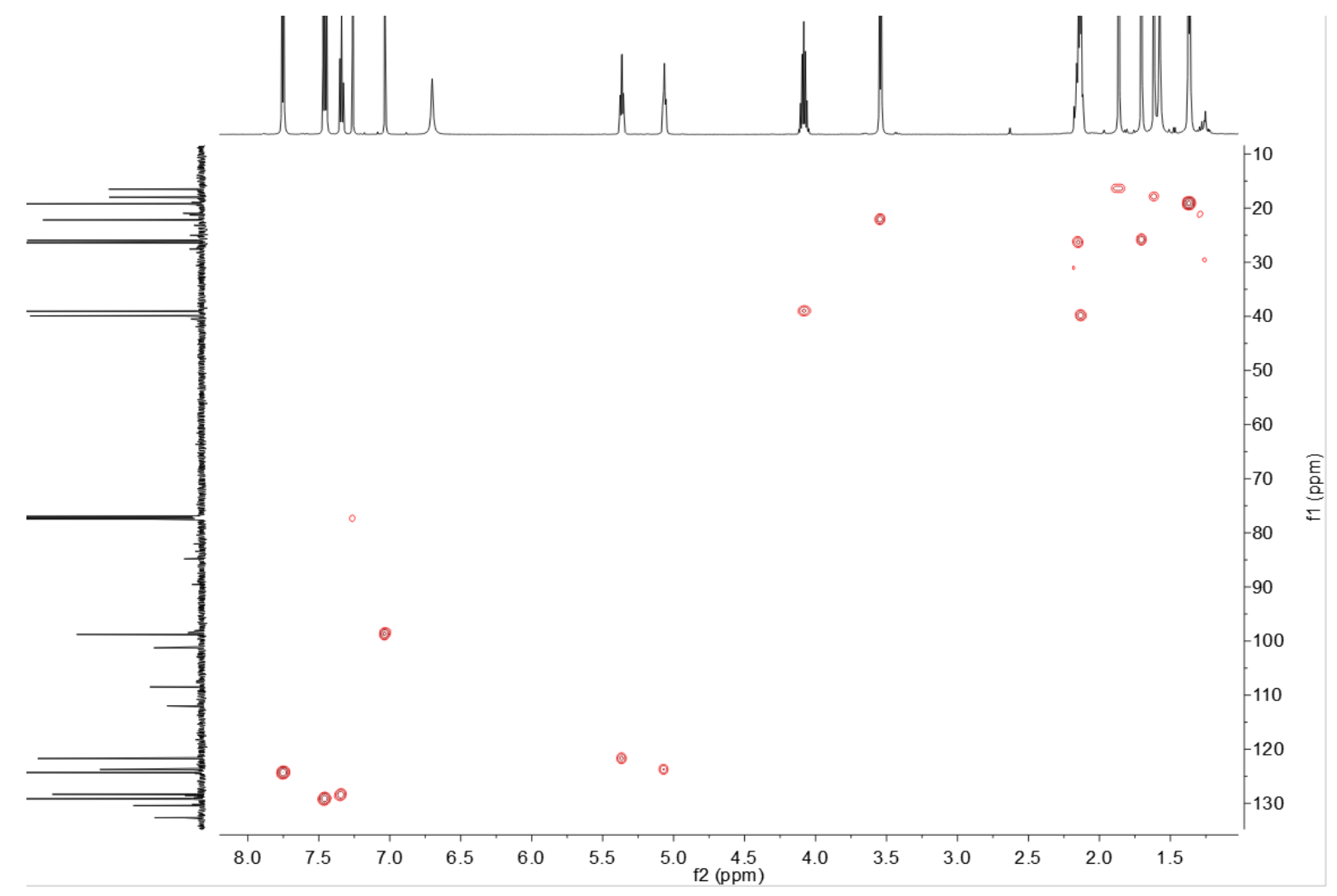

Figure S3. HSQC spectrum of $\mathbf{1}$.

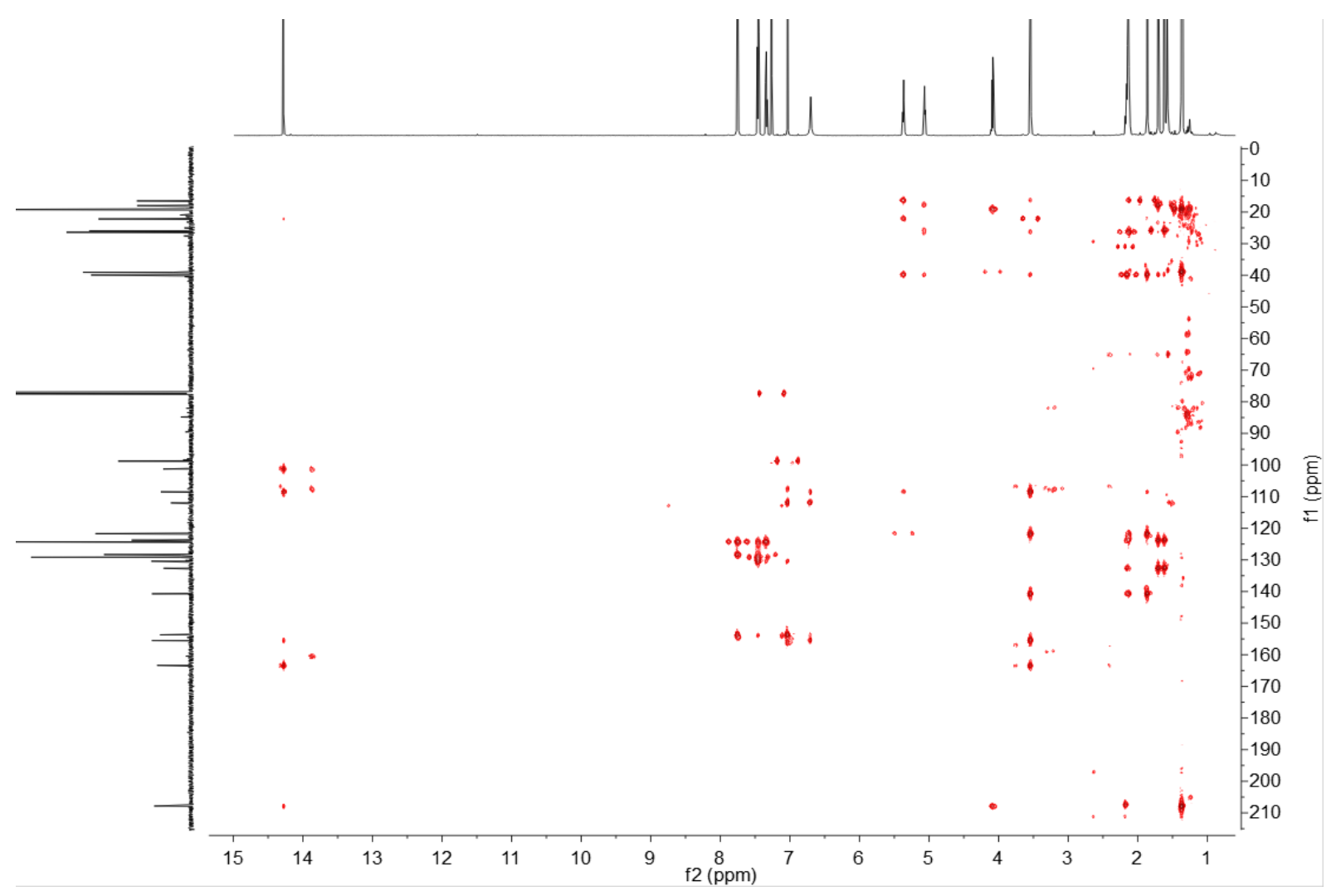

Figure S4. HMBC spectrum of $\mathbf{1}$. 


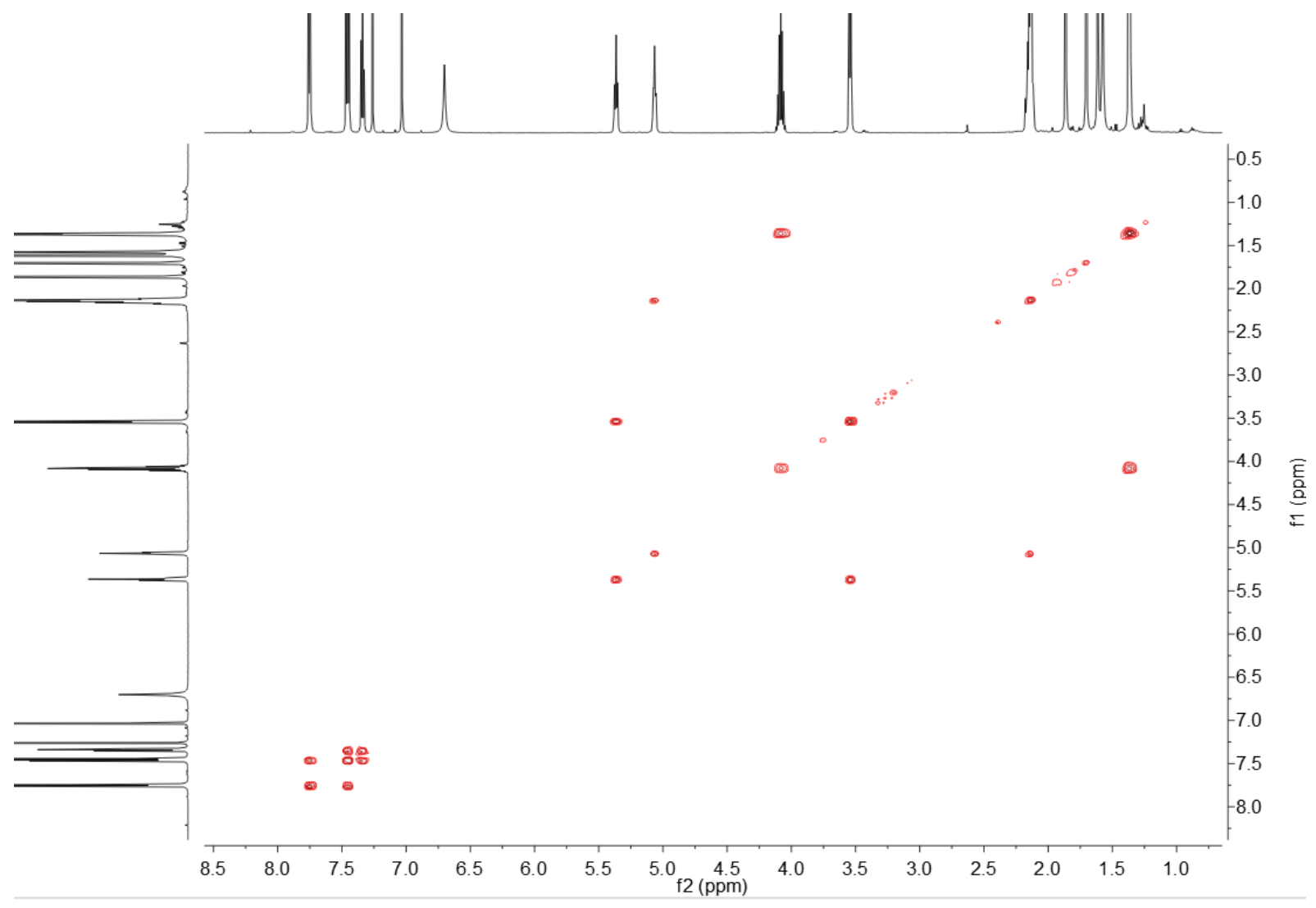

Figure S5. ${ }^{1} \mathrm{H}-{ }^{1} \mathrm{H}$ COSY spectrum of $\mathbf{1}$.

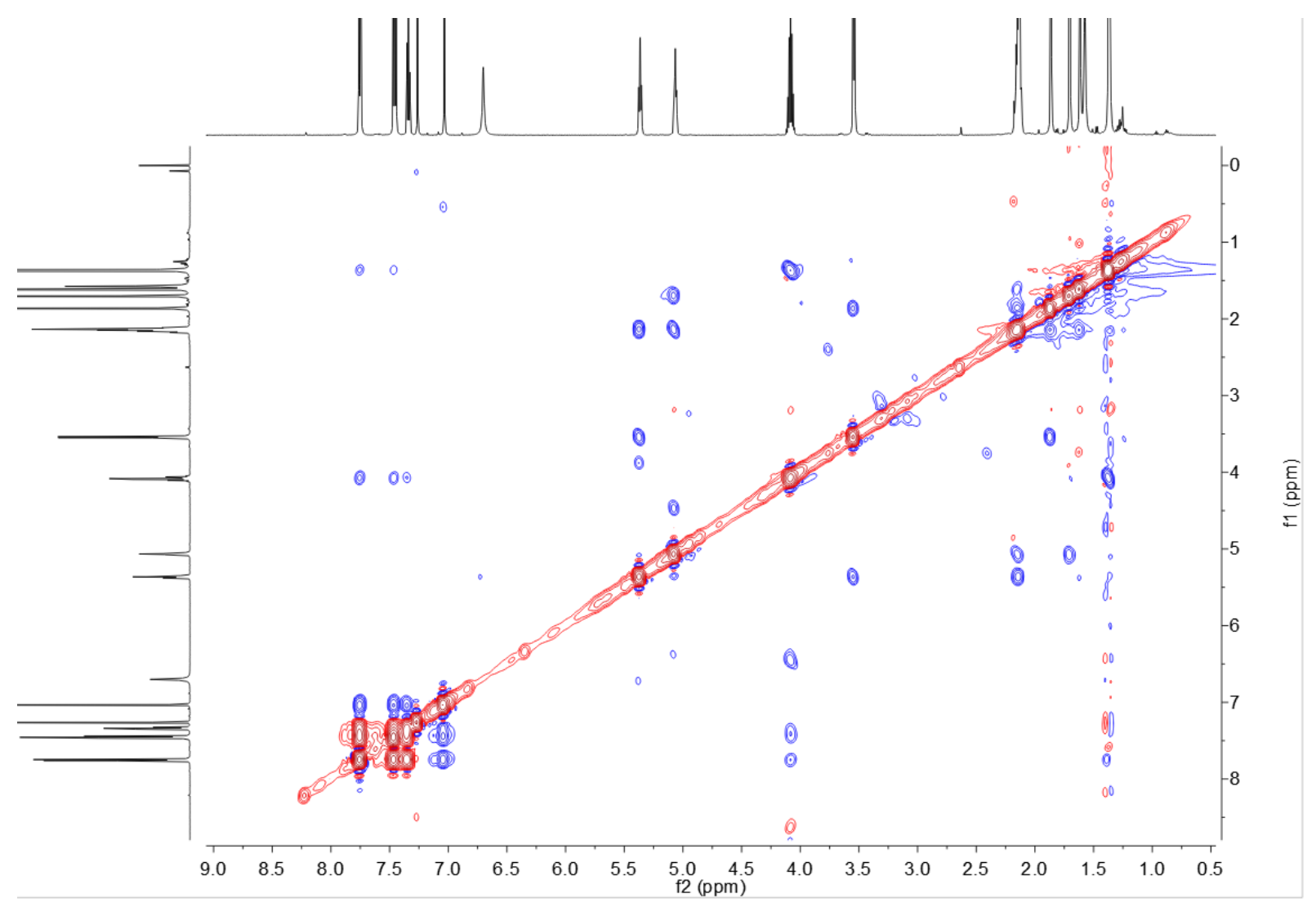

Figure S6. ROESY spectrum of $\mathbf{1}$. 


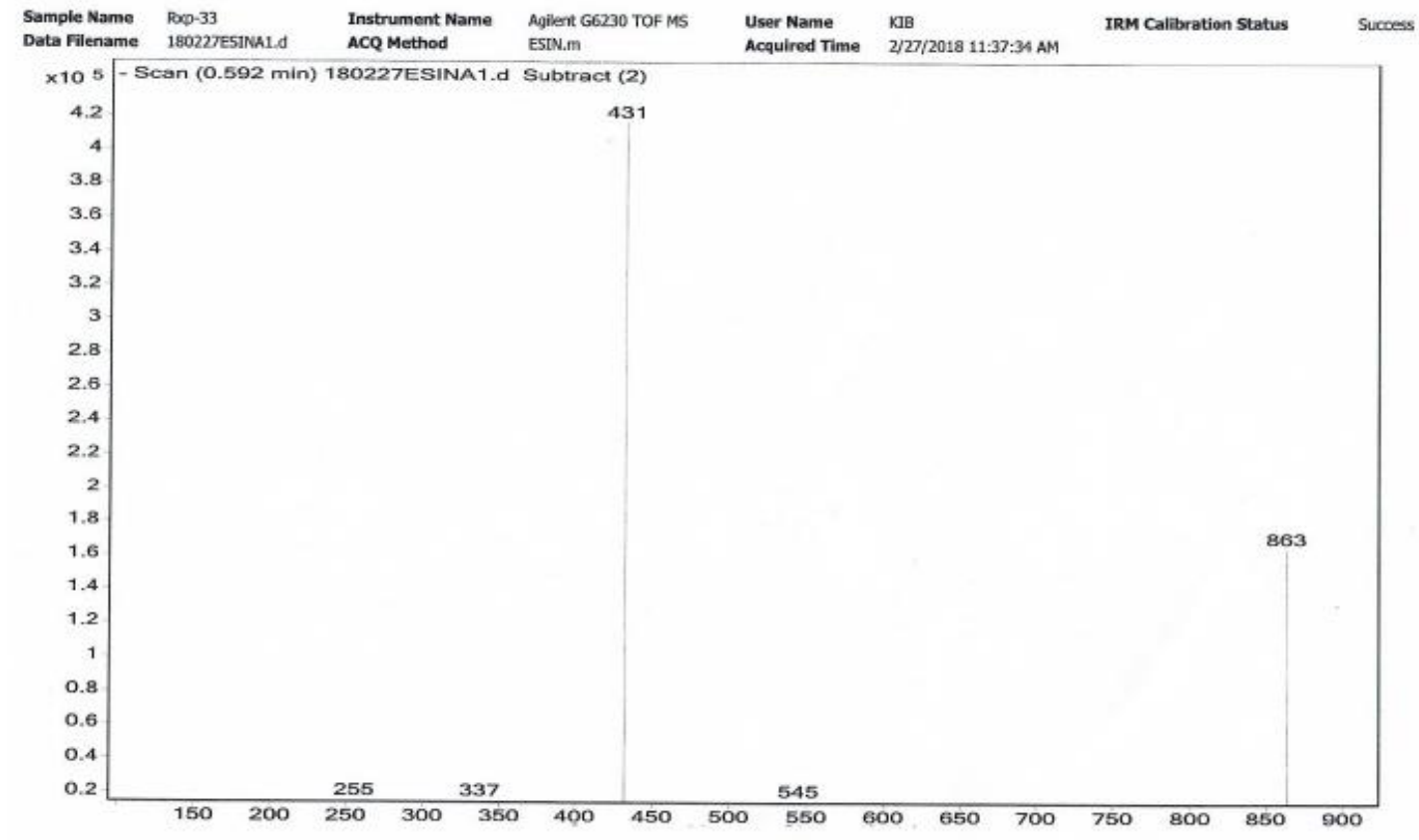

Figure S7. ESI-MS spectrum of $\mathbf{1}$. 
Qualitative Analysis Report

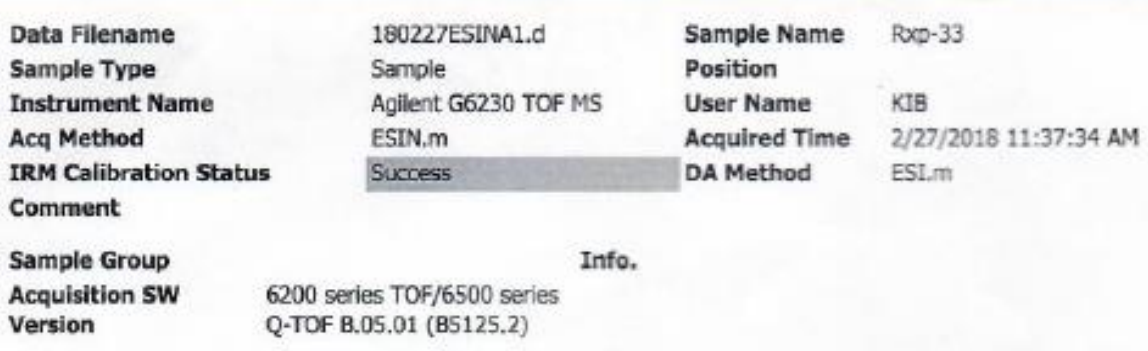

User Spectra

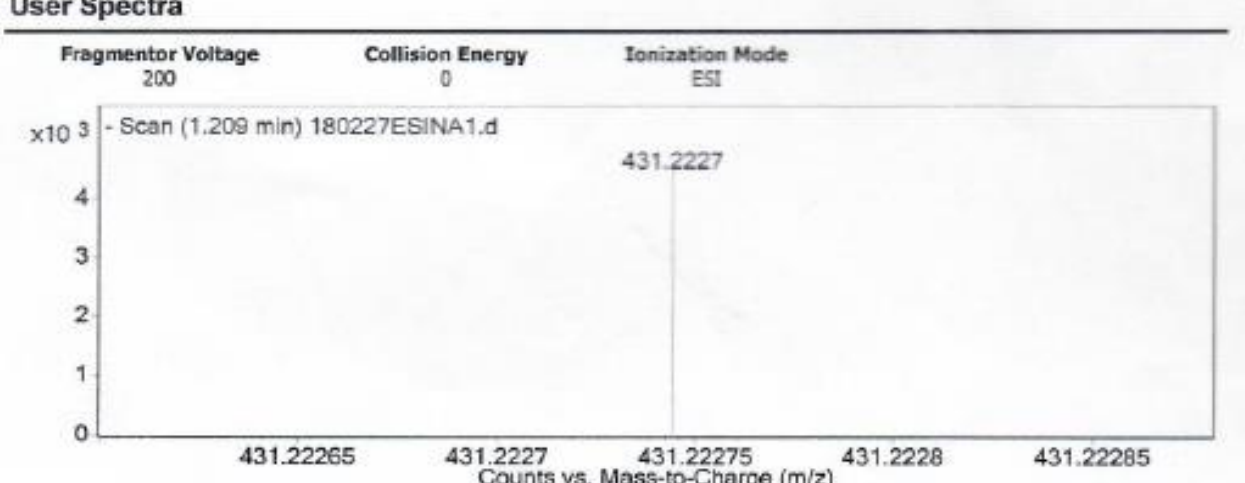

Peak List

\begin{tabular}{|l|l|l|l|l|}
\hline $\mathrm{m} / \mathbf{z}$ & $\mathrm{z}$ & Abund & Formula & Ion \\
\hline 112.9856 & & 1784.42 & & \\
\hline 174.9671 & & 281.23 & & \\
\hline 268.9551 & & 1073.23 & & \\
\hline 362.9418 & & 242.04 & & \\
\hline 431.2227 & 1 & 4627.41 & $\mathrm{C} 28 \mathrm{H} 31$ O4 & $\mathrm{M}-$ \\
\hline 432.2272 & 1 & 666.61 & $\mathrm{C} 28 \mathrm{H} 31$ O4 & $\mathrm{M}-$ \\
\hline 863.4519 & & 287.45 & & \\
\hline 1033.9881 & 1 & 11929.76 & & \\
\hline 1034.9882 & 1 & 636.72 & & \\
\hline
\end{tabular}

\begin{tabular}{l|c|c|c}
\hline 1034.9882 & 1 & 636.72 & \\
\hline Formula Calculator Element Limits
\end{tabular}

Element Min

\begin{tabular}{|l|r|c|}
\hline $\mathrm{C}$ & 0 & 200 \\
\hline $\mathrm{H}$ & 0 & 400 \\
\hline $\mathrm{O}$ & 0 & 10 \\
\hline
\end{tabular}

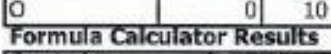

\begin{tabular}{l|l} 
Formula & CalculatedMass
\end{tabular}

\begin{tabular}{|l|r|r|r|r|r|}
\hline $\mathrm{C} 28 \mathrm{H} 3104$ & 431.2222 & 431.2227 & Diff.(mDa) & Diff. (ppm) & DBE \\
\hline
\end{tabular}

- End of Report --

Figure S8. HR-ESIMS spectrum of $\mathbf{1}$. 


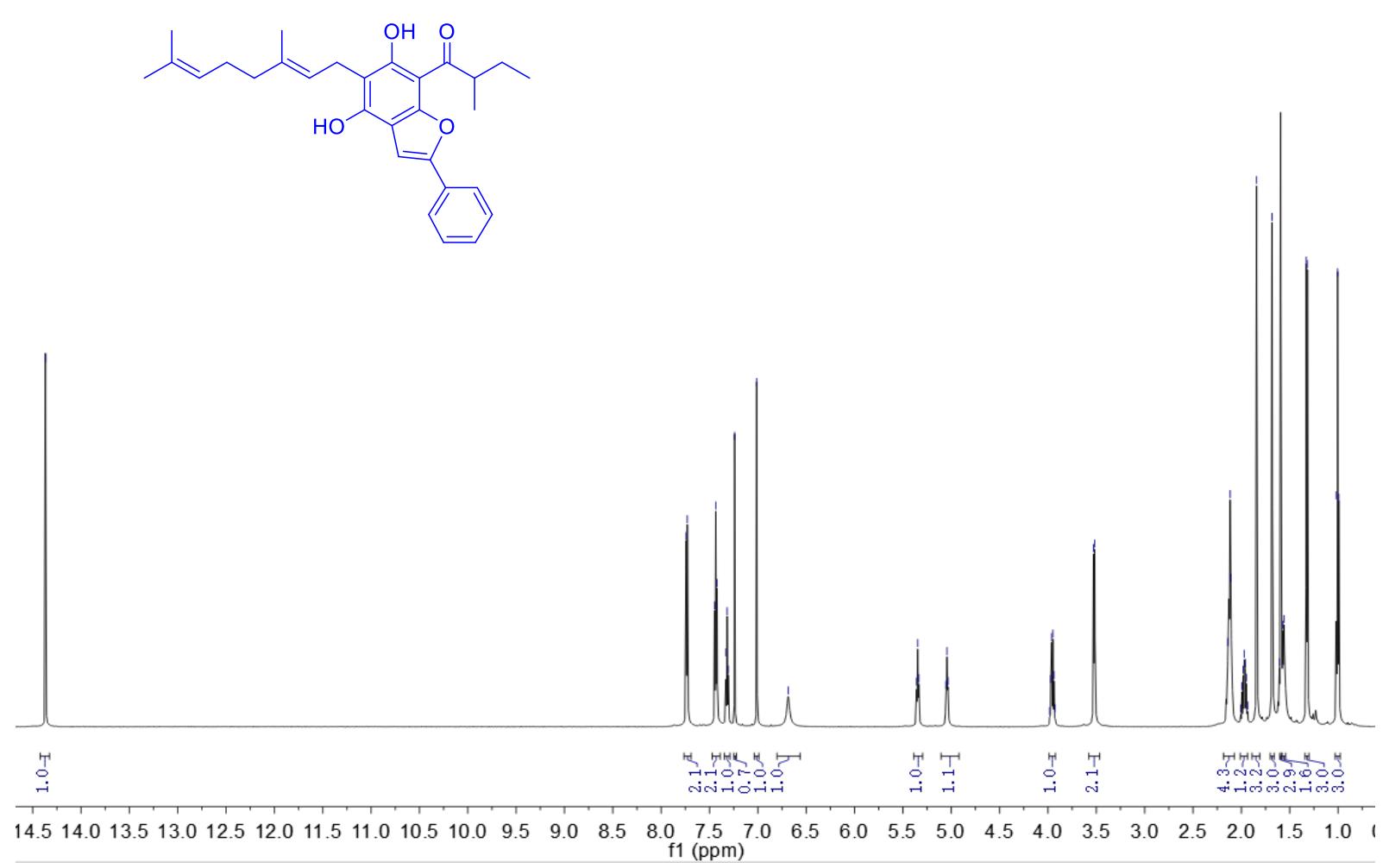

Figure S9. ${ }^{1} \mathrm{H}\left(\right.$ in $\left.\mathrm{CDCl}_{3}\right)$ spectrum of 2 .
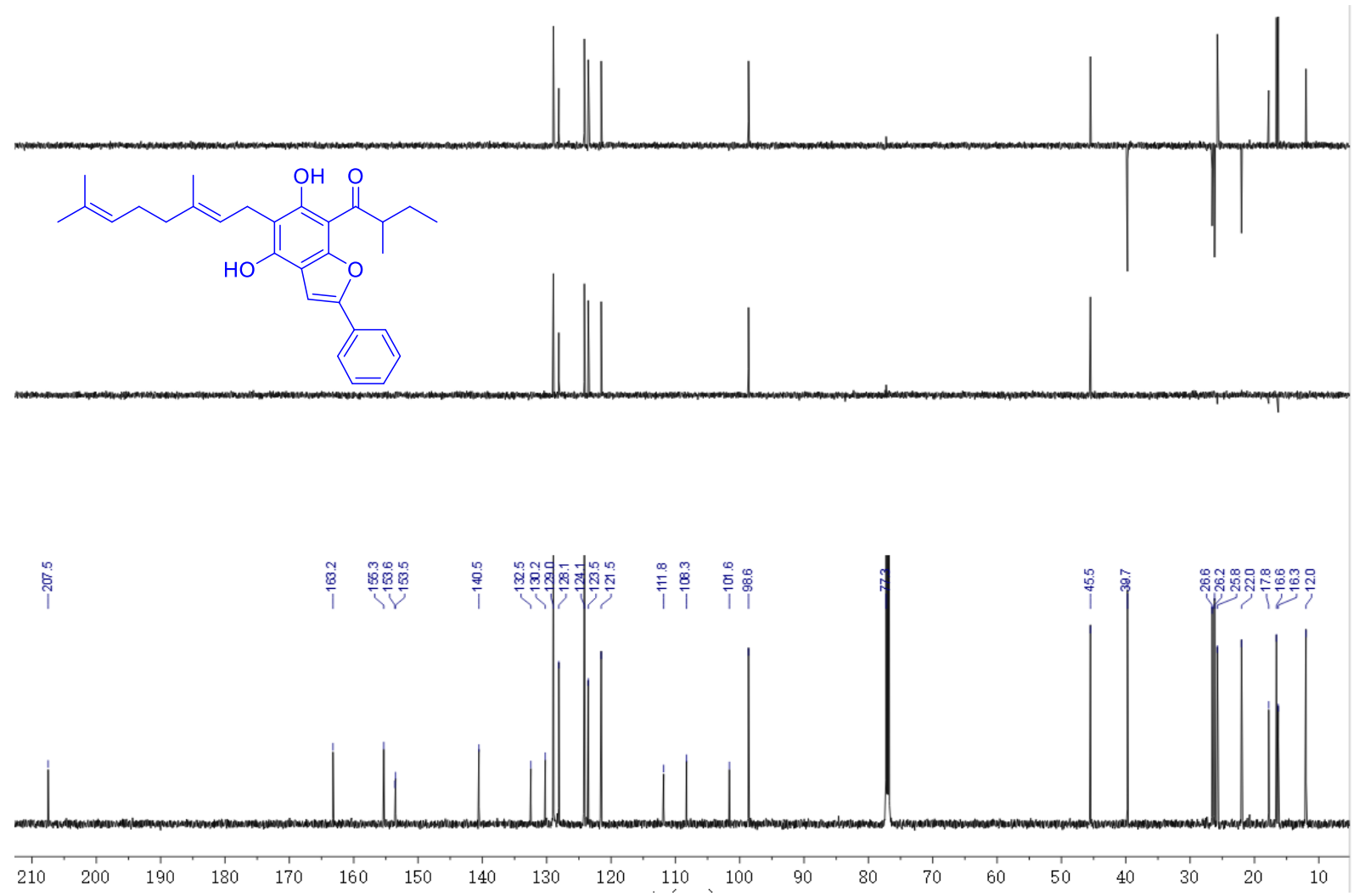

Figure S10. ${ }^{13} \mathrm{C}$ and DEPT (in $\mathrm{CDCl}_{3}$ ) spectrum of 2. 


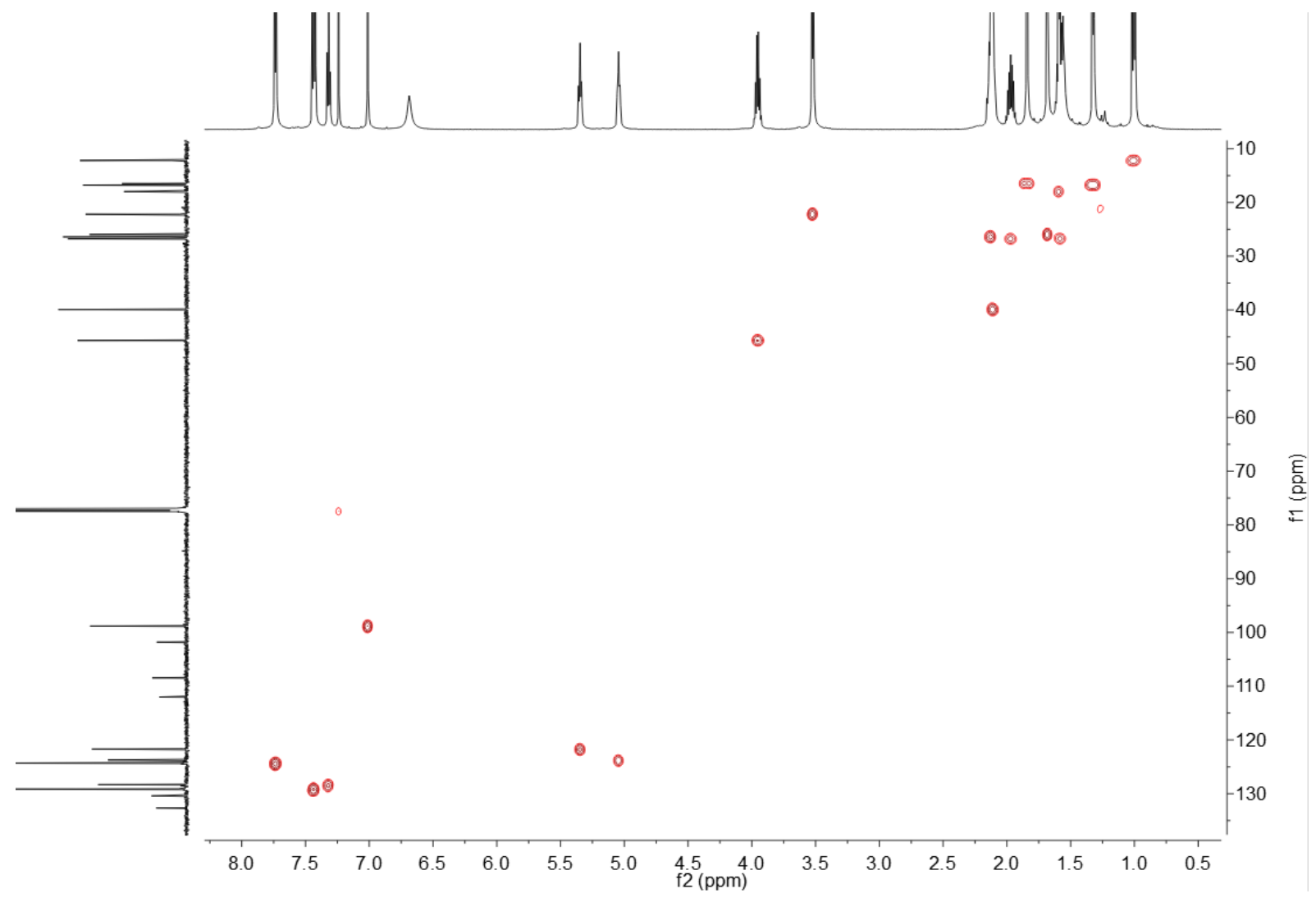

Figure S11. HSQC spectrum of 2.

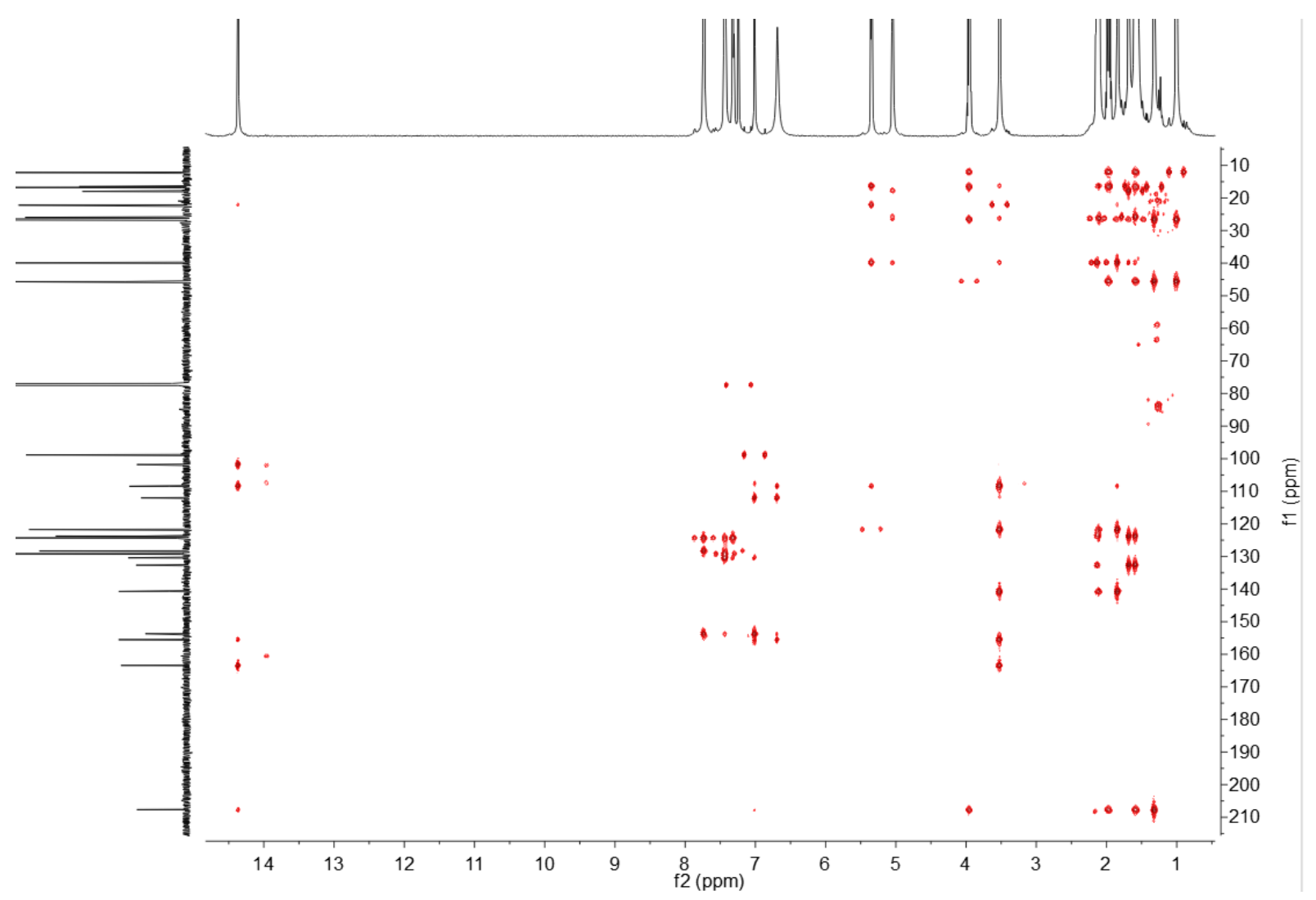

Figure S12. HMBC spectrum of 2. 


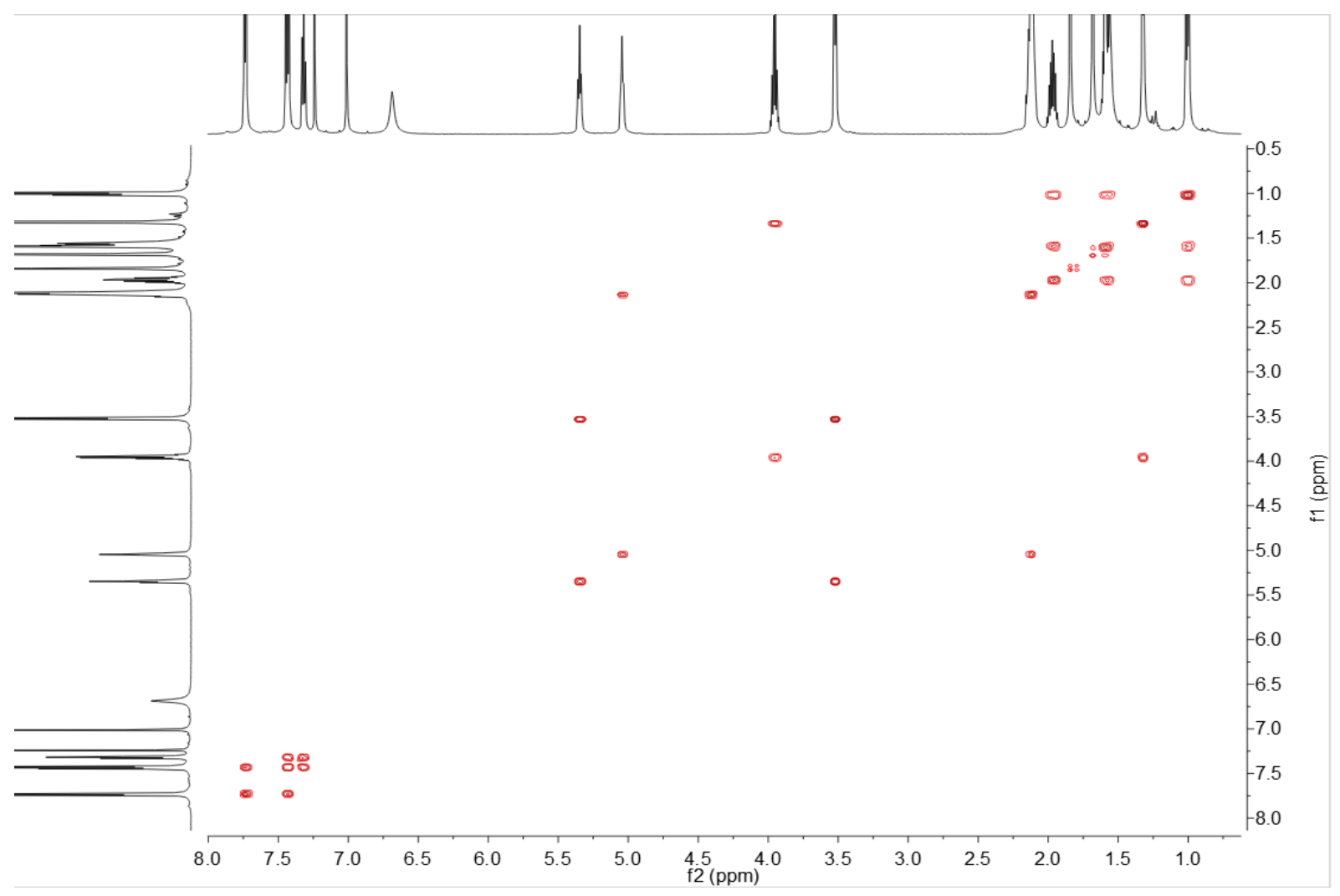

Figure S13. ${ }^{1} \mathrm{H}-{ }^{1} \mathrm{H}$ COSY spectrum of 2.

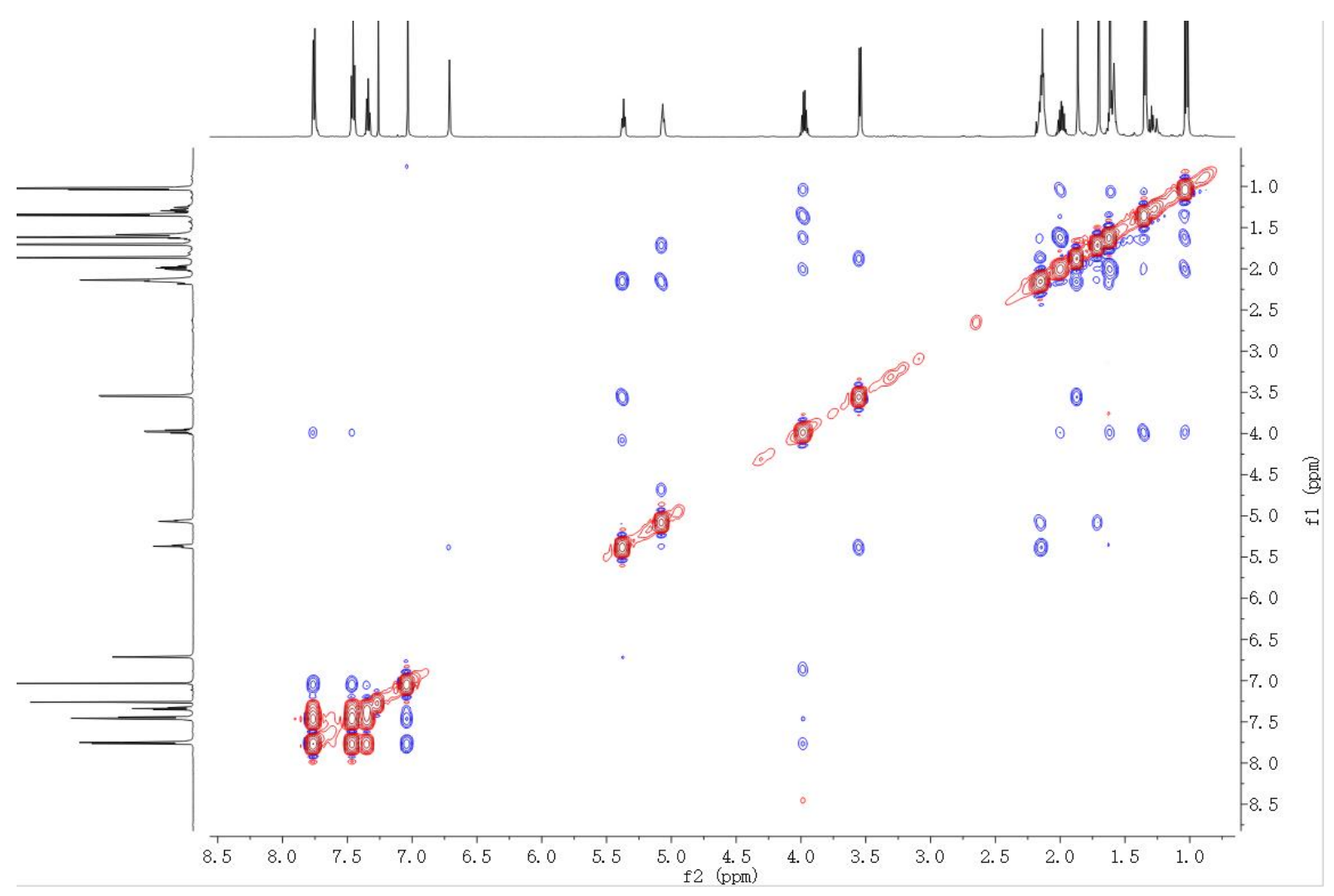

Figure S14. ROESY spectrum of 2. 


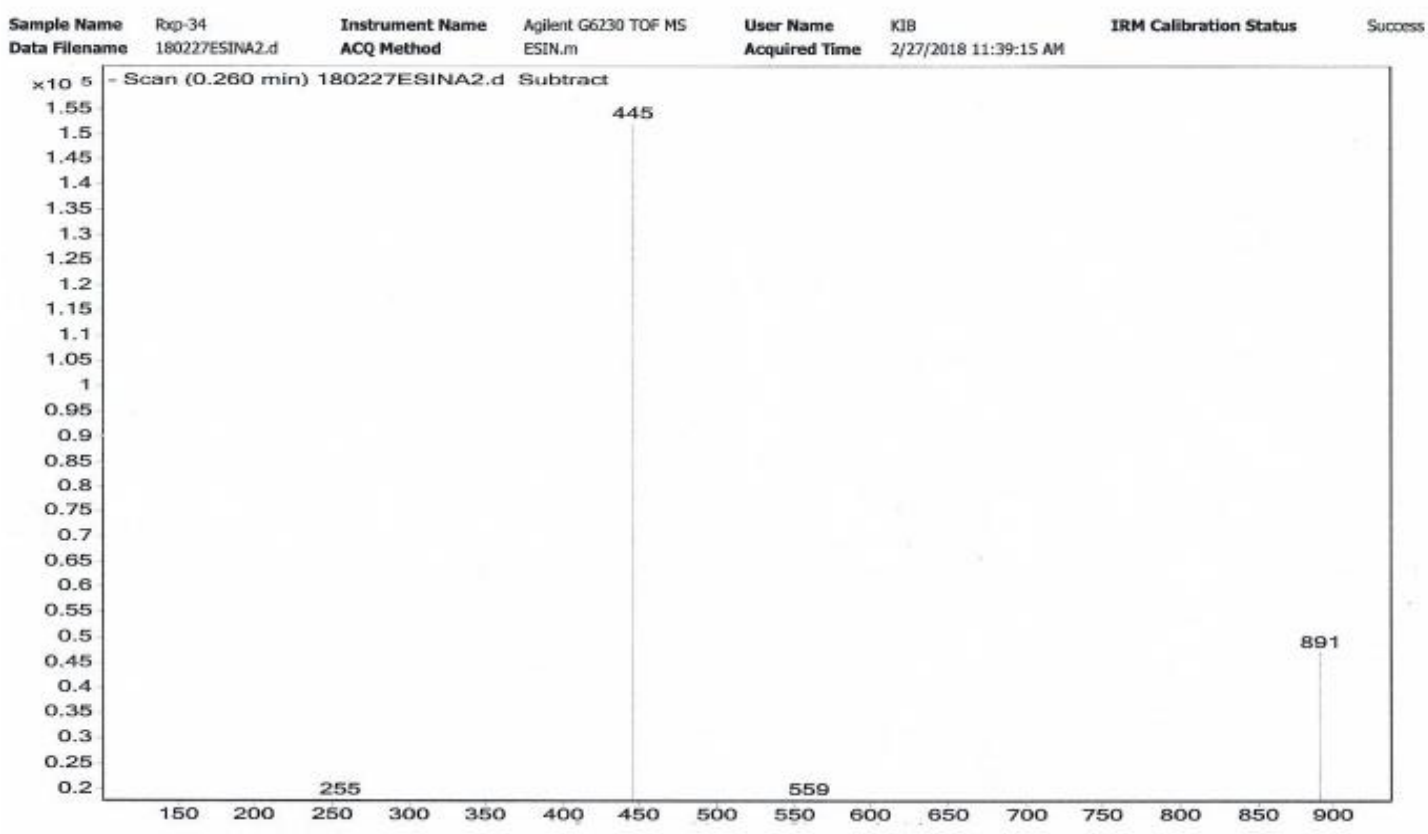

Figure S15. ESI-MS spectrum of 2. 


\section{Qualitative Analysis Report}

Data Filename

Sample Type

Instrument Name

Acq Method

IRM Calibration Status

Comment

Sample Group

Acquisition SW

Version
180227ESINA2.d

Sample

Agllent G6230 TOF MS

ESIN,m

Success
Sample Name

Position

User Name

Acquired Time $\quad 2 / 27 / 2018$ 11:39:15 AM

DA Method ESI.m
$\operatorname{Rxp}-34$

(IB

Info.

6200 serles TOF/6500 series

Q-TOF B.05.01 (B5125.2)

User Spectra

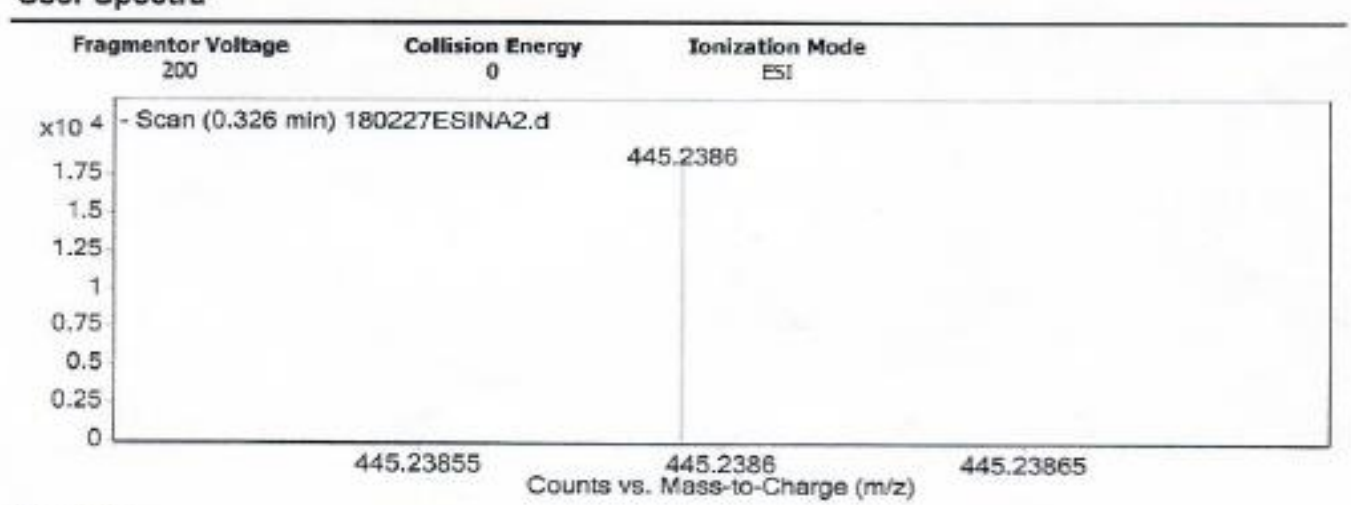

\begin{tabular}{|c|c|c|c|}
\hline \multicolumn{4}{|l|}{ Peak List } \\
\hline$m / z$ & $z$ & \multicolumn{2}{|c|}{ Abund } \\
\hline 112.9856 & & \multicolumn{2}{|c|}{2347.77} \\
\hline 119.0363 & & \multicolumn{2}{|c|}{230.62} \\
\hline 154.9727 & & \multicolumn{2}{|c|}{259.4} \\
\hline 445.2386 & 1 & \multicolumn{2}{|c|}{18588.57} \\
\hline 446.2416 & 1 & \multicolumn{2}{|c|}{2232.5} \\
\hline 891.4842 & 1 & \multicolumn{2}{|c|}{1780.45} \\
\hline 892.4843 & 1 & \multicolumn{2}{|c|}{790.45} \\
\hline 1033.9881 & 1 & \multicolumn{2}{|c|}{174929.3} \\
\hline 1034.9893 & 1 & \multicolumn{2}{|c|}{20657.87} \\
\hline 1035.9915 & 1 & \multicolumn{2}{|c|}{668} \\
\hline \multirow{2}{*}{\multicolumn{4}{|c|}{$\begin{array}{l}\text { Formula Calculator Element } \\
\text { Element } 1 \text { Min } \mid \text { Max }\end{array}$}} \\
\hline & & & \\
\hline $\mathrm{C}$ & & 0 & 200 \\
\hline $\mathrm{H}$ & & 0 & 400 \\
\hline 0 & & 0 & 10 \\
\hline
\end{tabular}

\begin{tabular}{|l|r|r|r|r|r|}
\hline Formula & CalculatedMass & Mz & Diff.(mDa) & Dif. (Dpm) & DBE \\
\hline $\mathrm{C} 29 \mathrm{H} 33 \mathrm{O} 4$ & 445.2379 & 445.2386 & -0.7 & 1.6 & 13.5 \\
\hline
\end{tabular}

..- End Of Report -

Figure S16. HR-ESIMS spectrum of 2. 


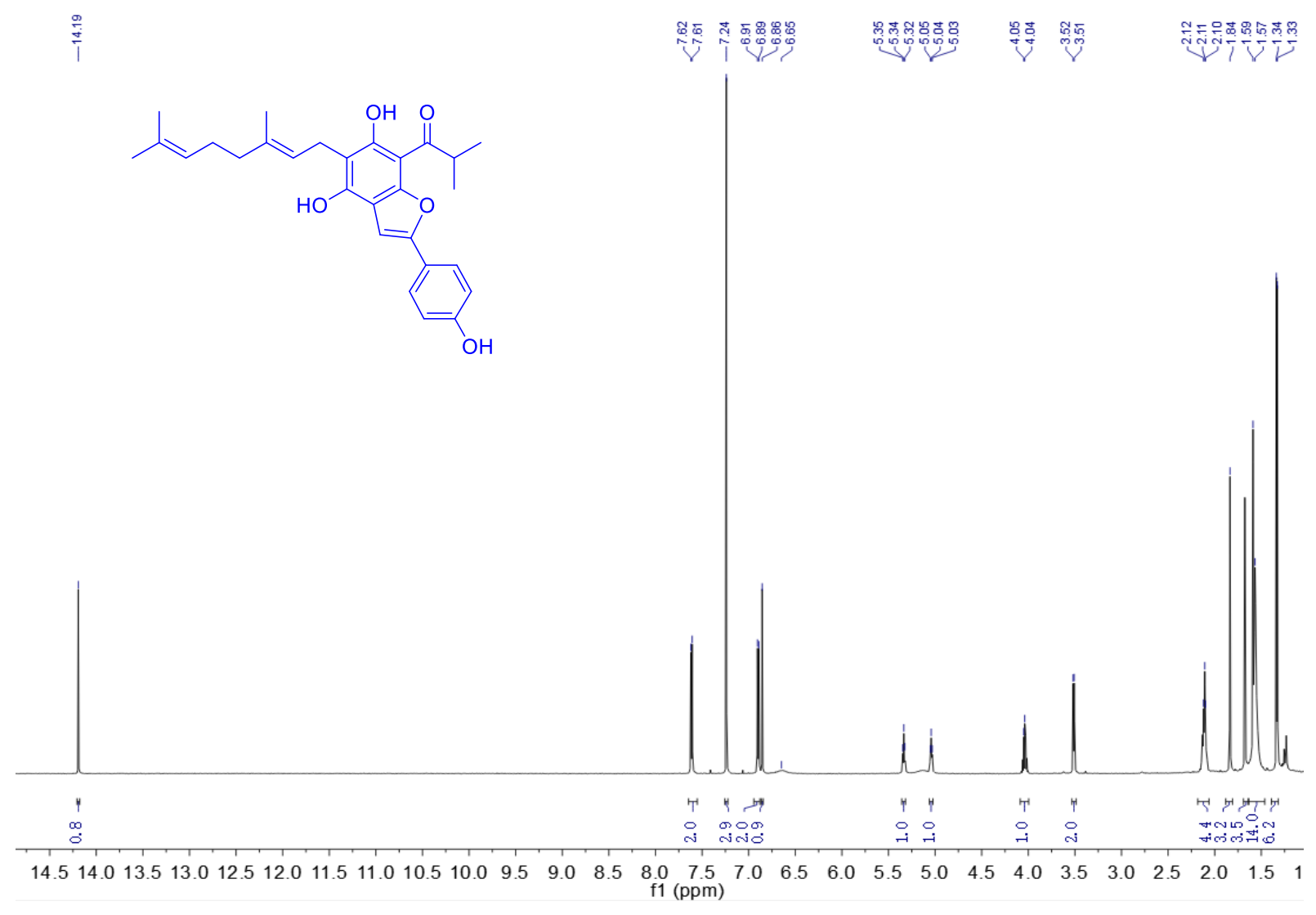

Figure S17. ${ }^{1} \mathrm{H}$ (in $\mathrm{CDCl}_{3}$ ) spectrum of 3.
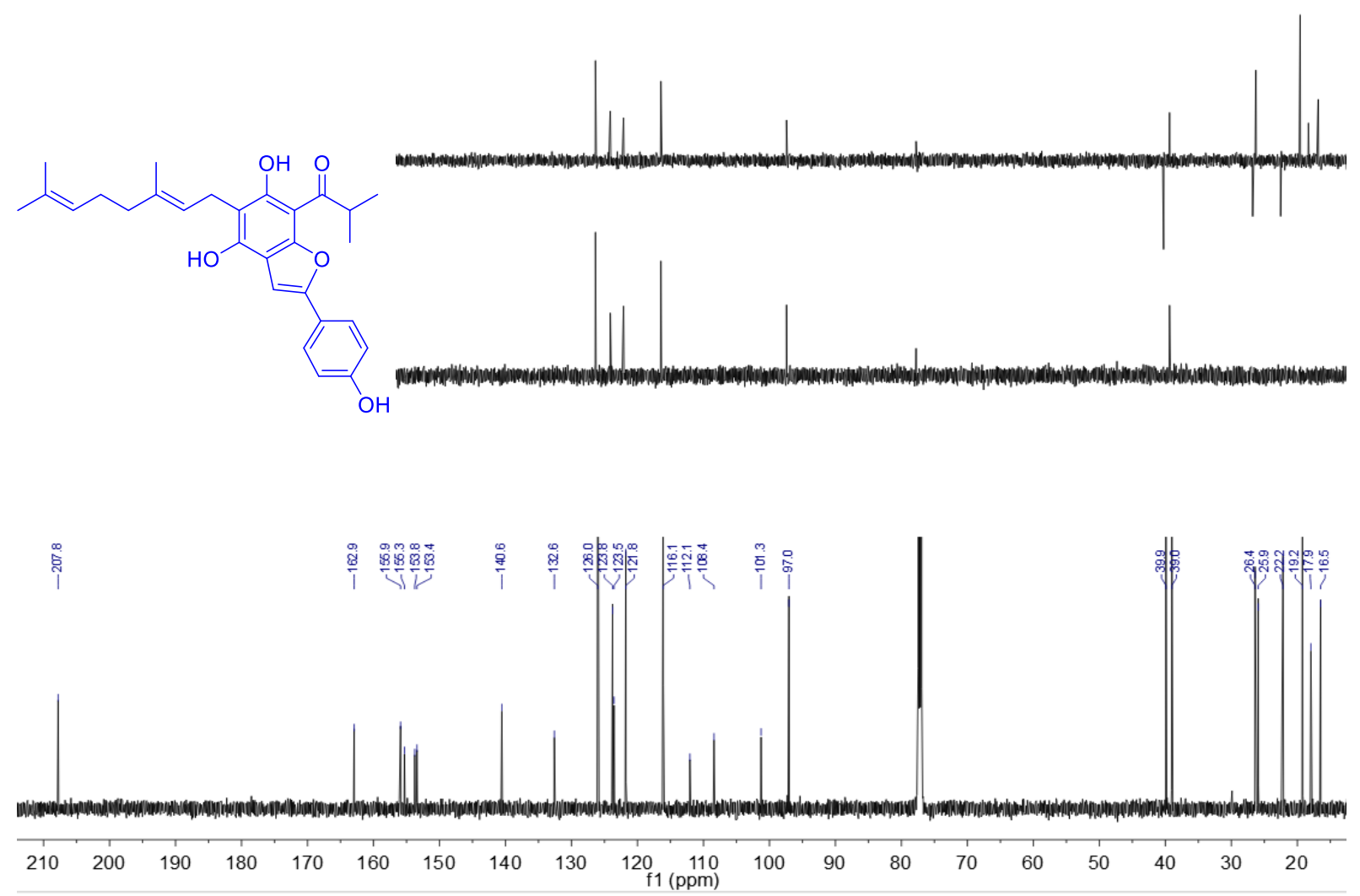

Figure S18. ${ }^{13} \mathrm{C}$ and DEPT (in $\mathrm{CDCl}_{3}$ ) spectra of $\mathbf{3}$. 


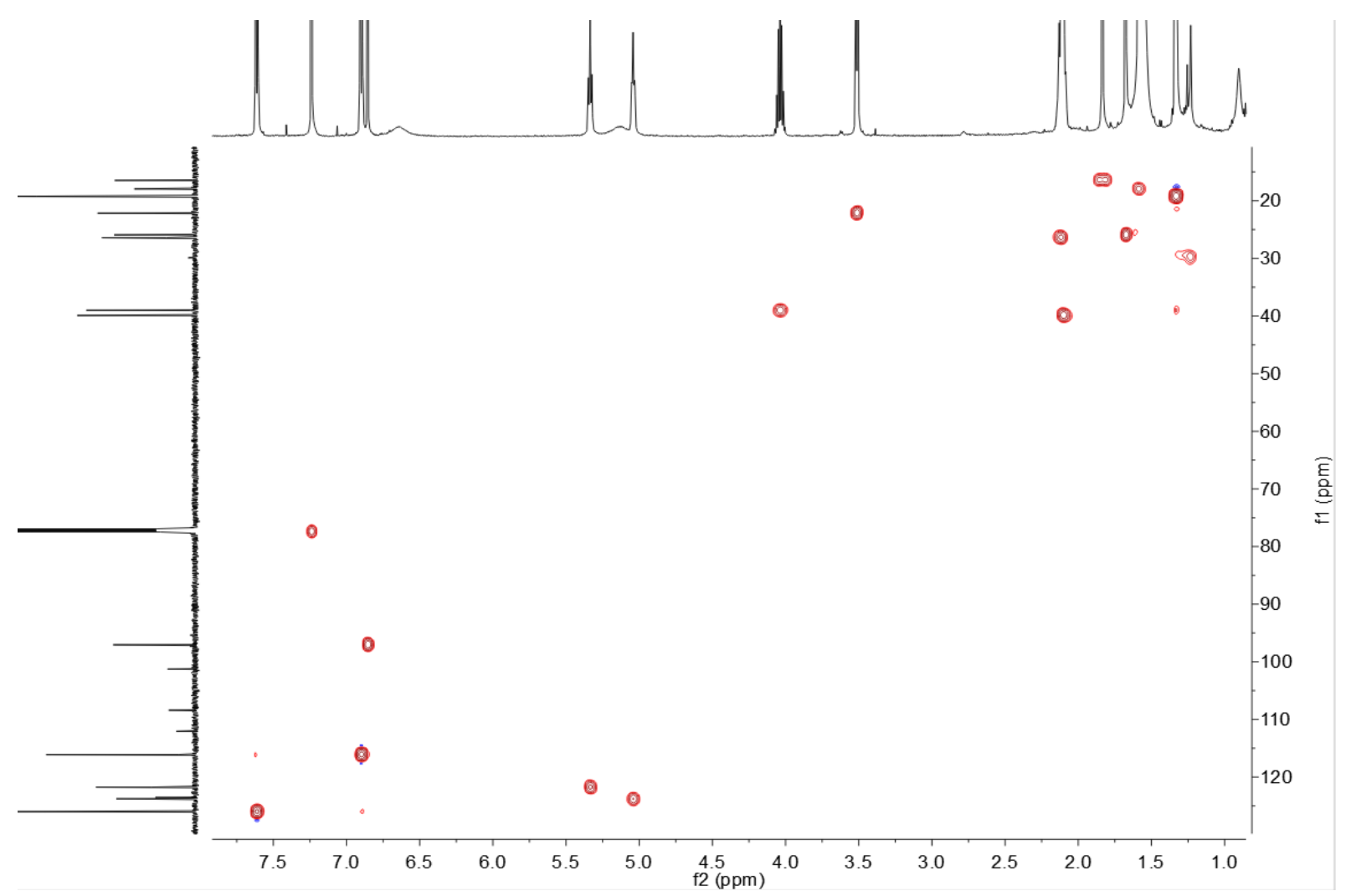

Figure S19. HSQC spectrum of 3.

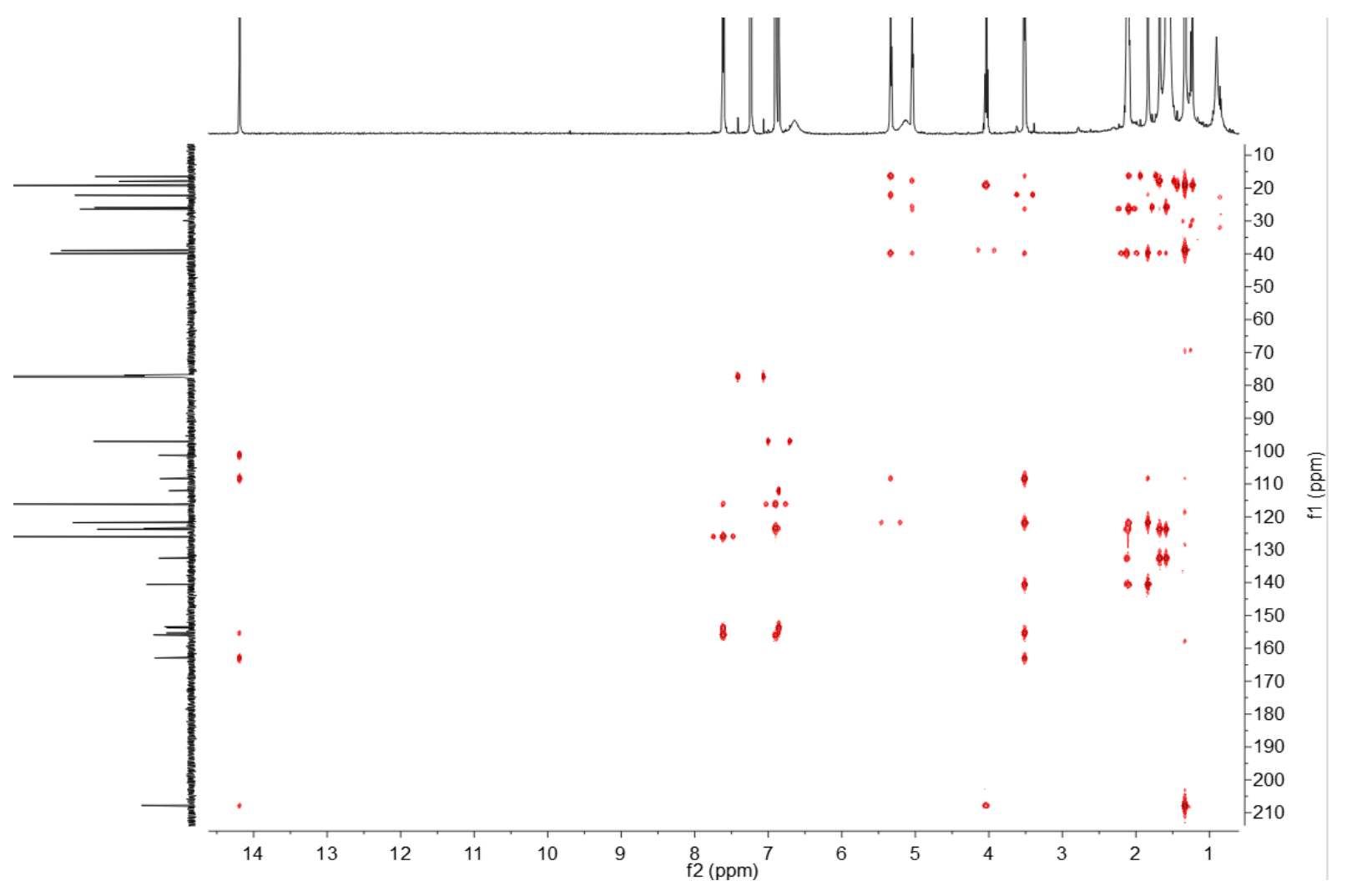

Figure S20. HMBC spectrum of $\mathbf{3}$. 


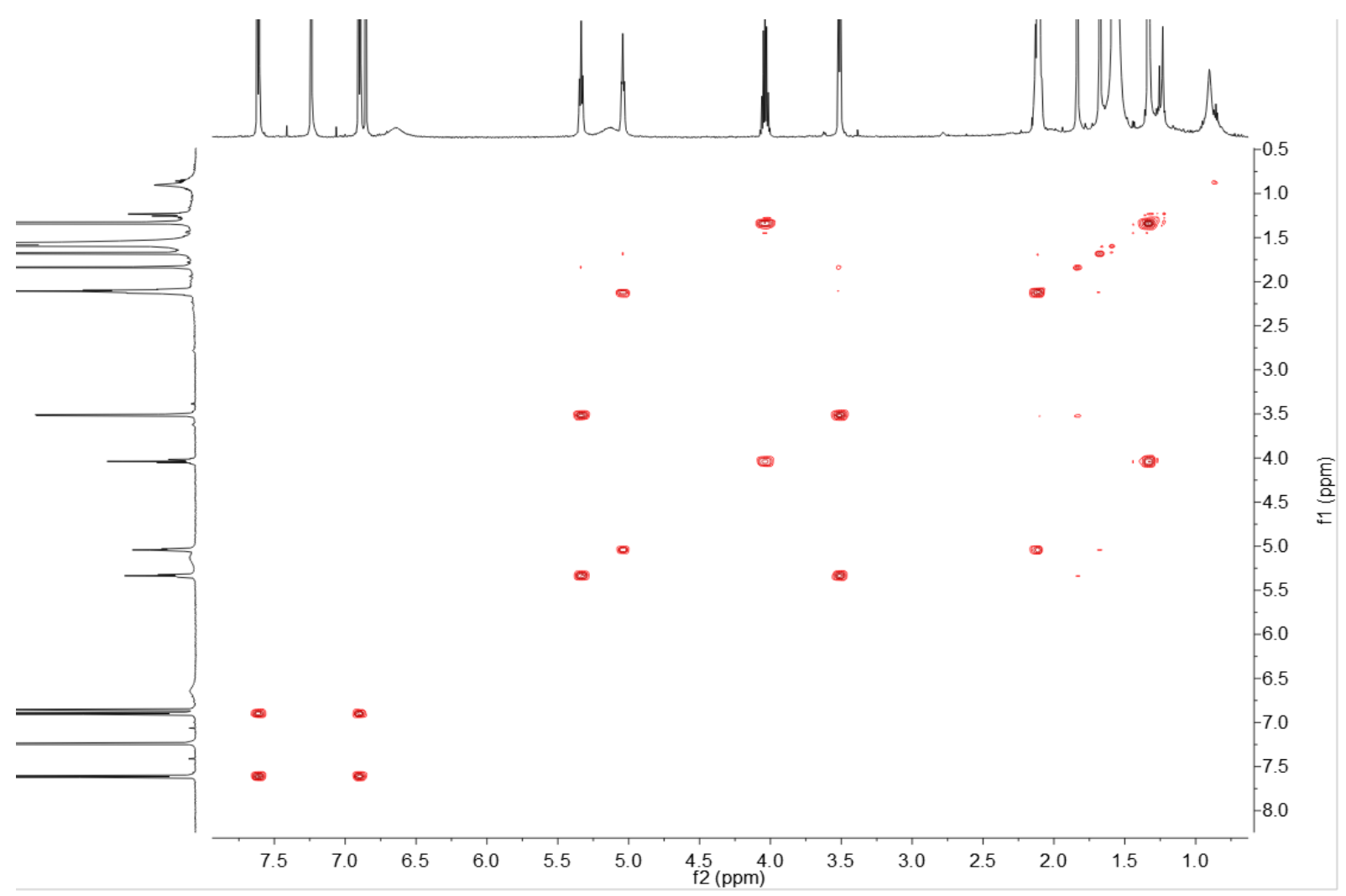

Figure S21. ${ }^{1} \mathrm{H}-{ }^{1} \mathrm{H}$ COSY spectrum of 3.

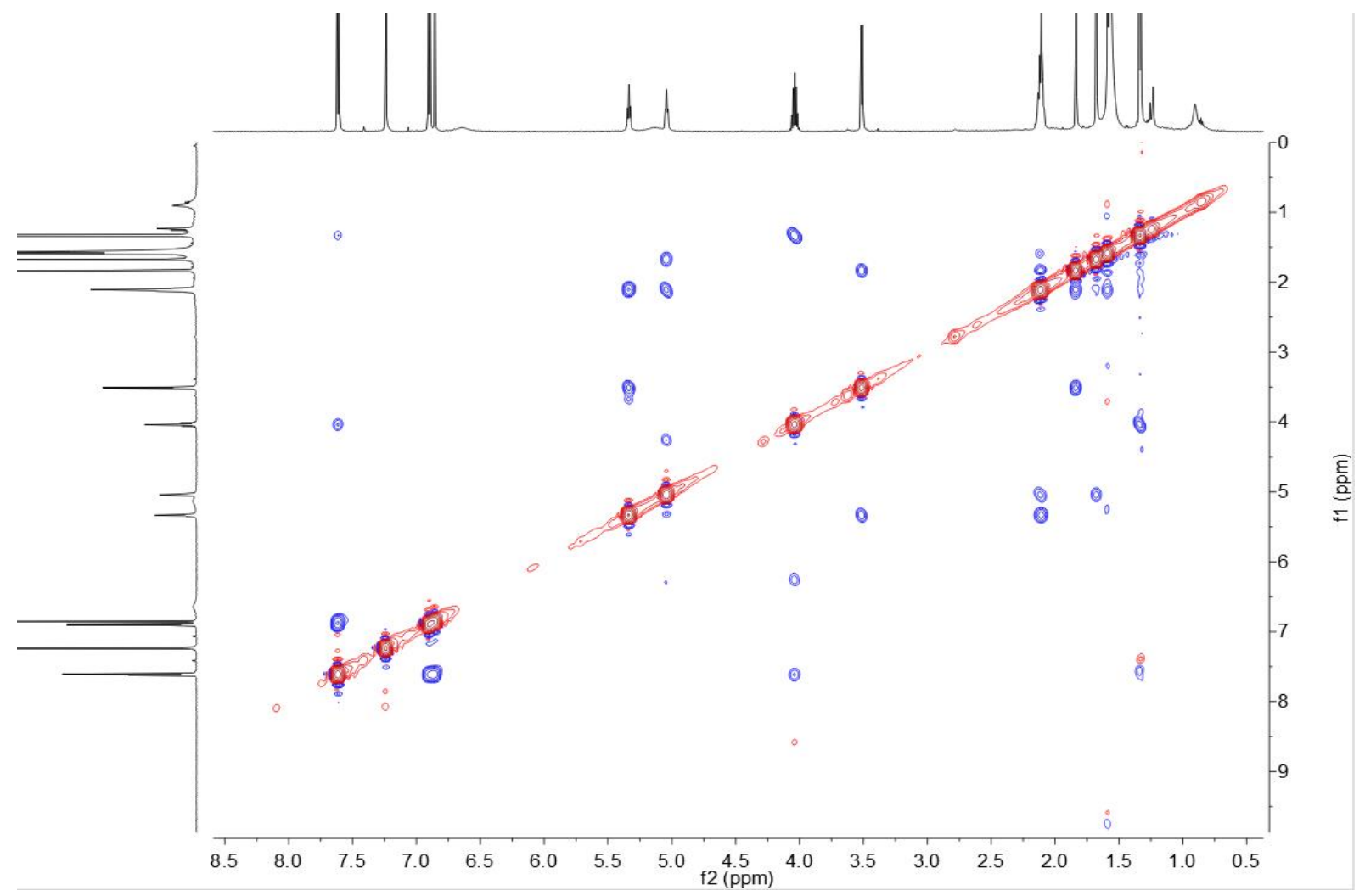

Figure S22. ROESY spectrum of 3. 


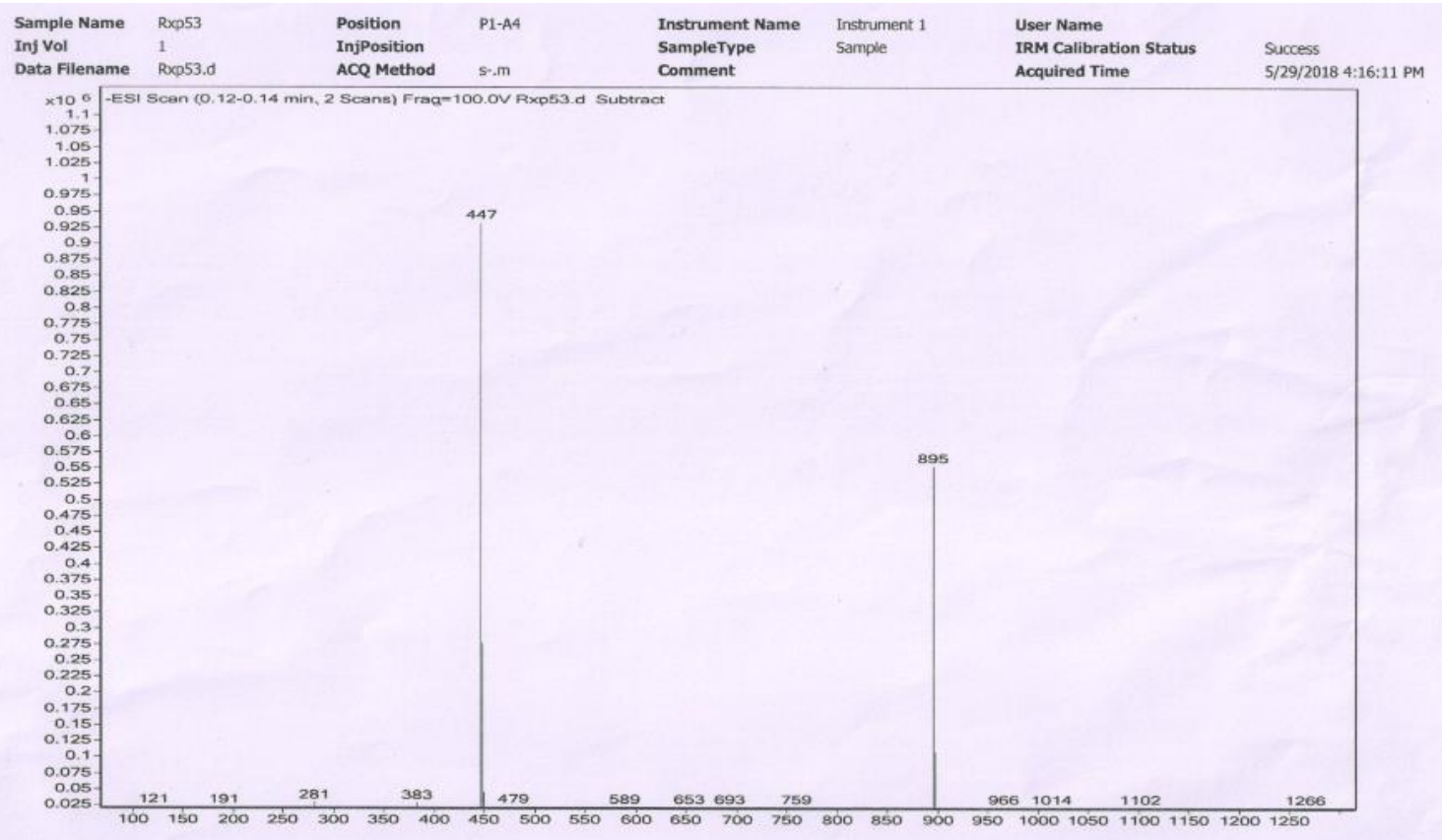

Figure S23. ESI-MS spectrum of 3. 
Qualitative Analysis Report

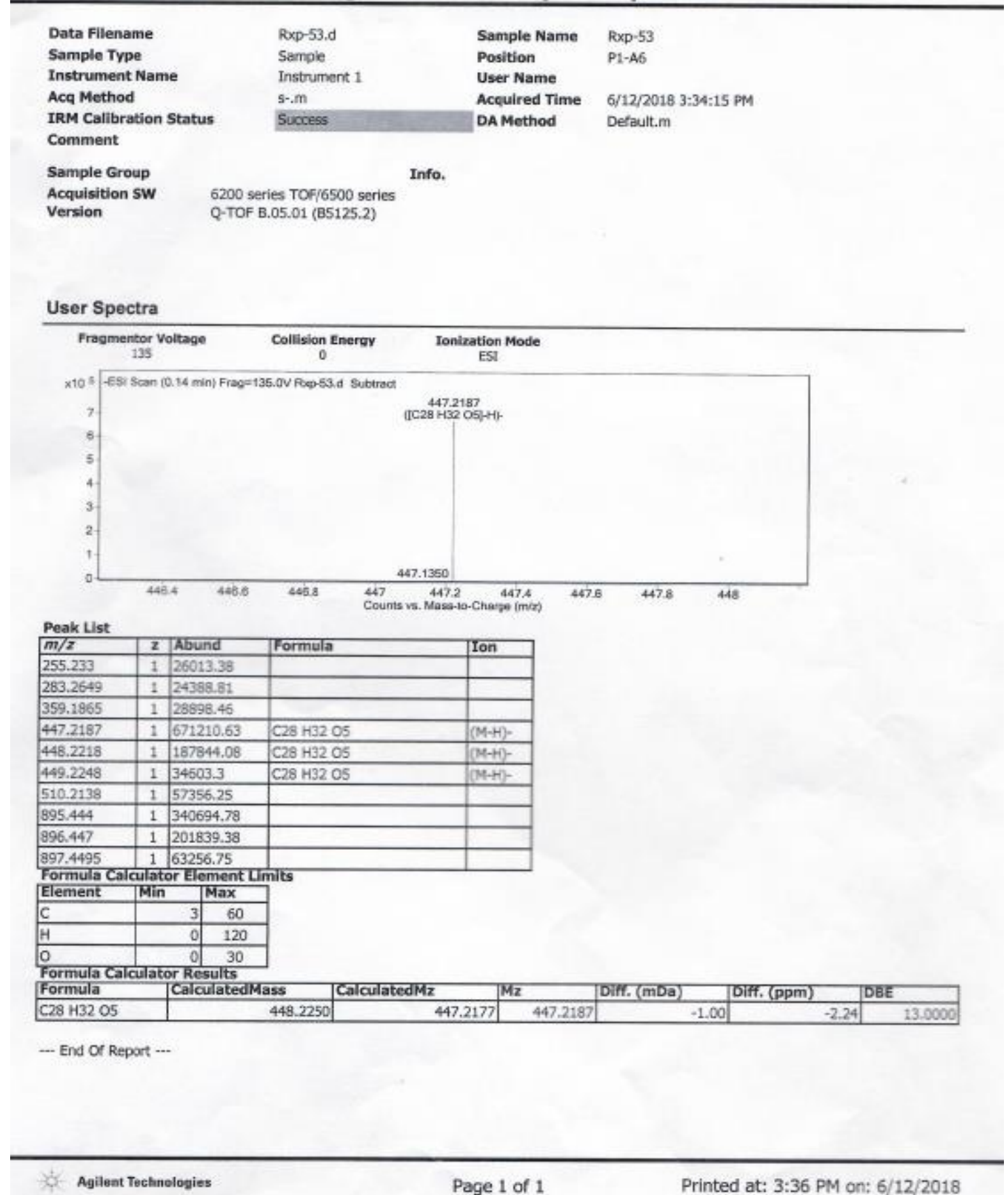

Figure S24. HR-ESIMS spectrum of 3. 
<smiles></smiles>

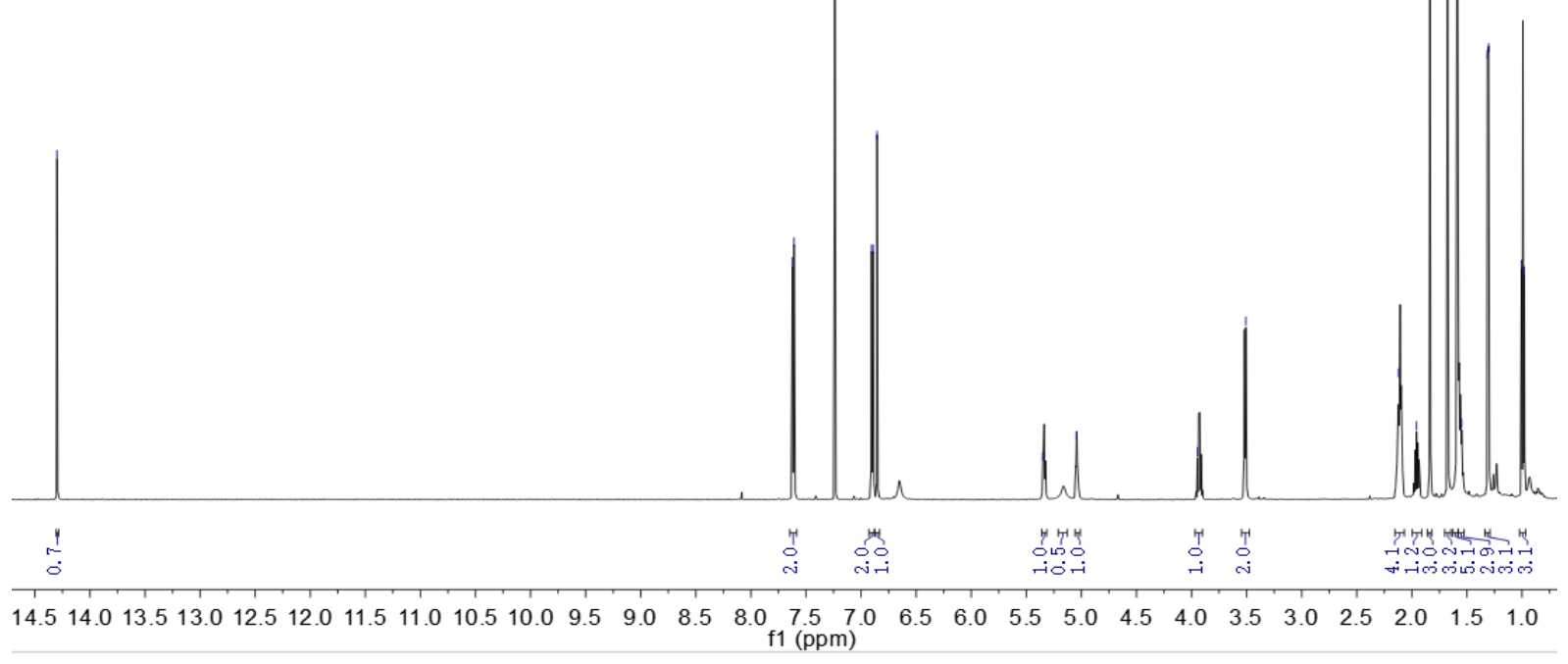

Figure S25. ${ }^{1} \mathrm{H}$ (in $\mathrm{CDCl}_{3}$ ) spectrum of 4.
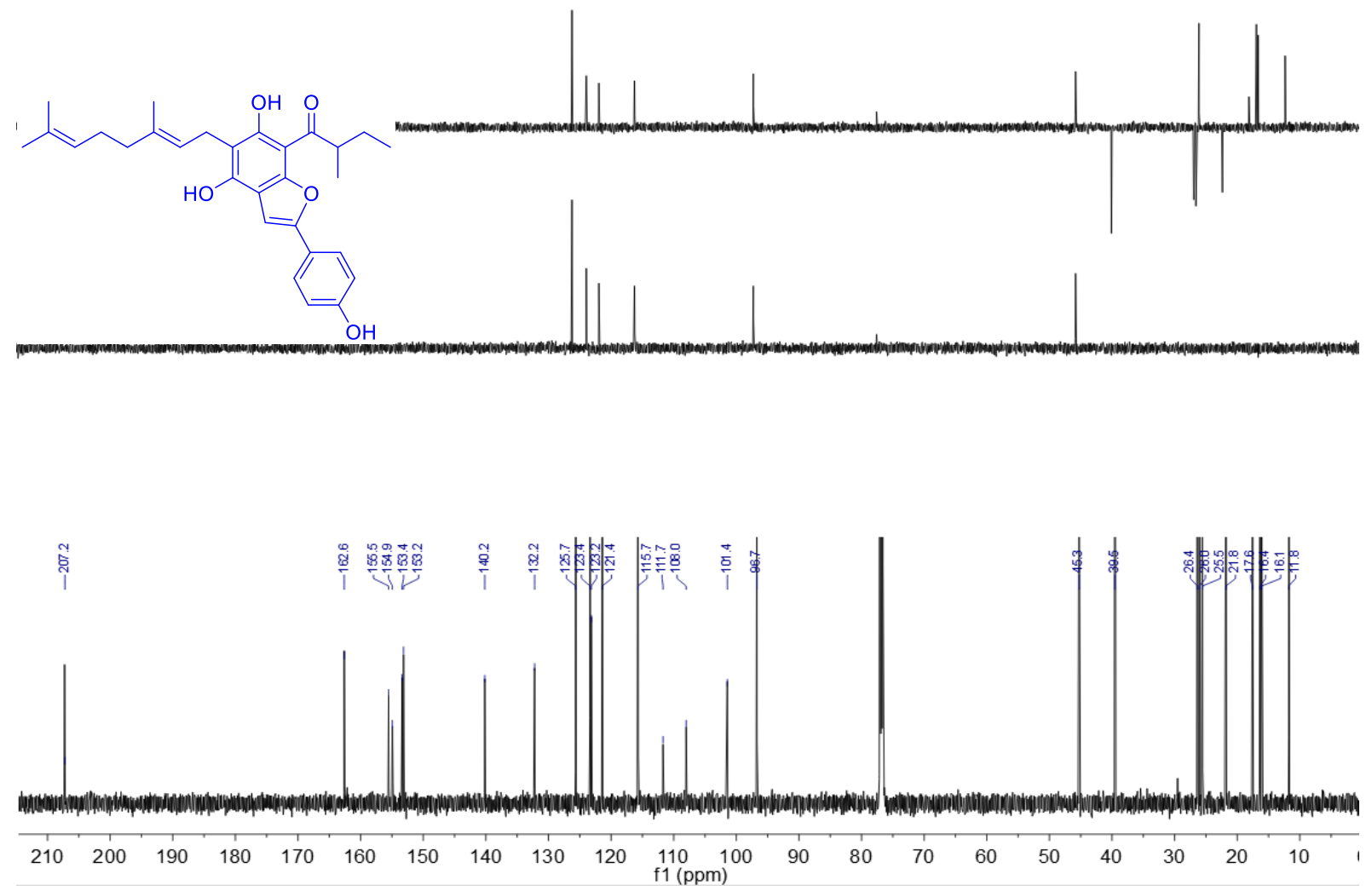

Figure S26. ${ }^{13} \mathrm{C}$ and DEPT (in $\mathrm{CDCl}_{3}$ ) spectra of 4. 


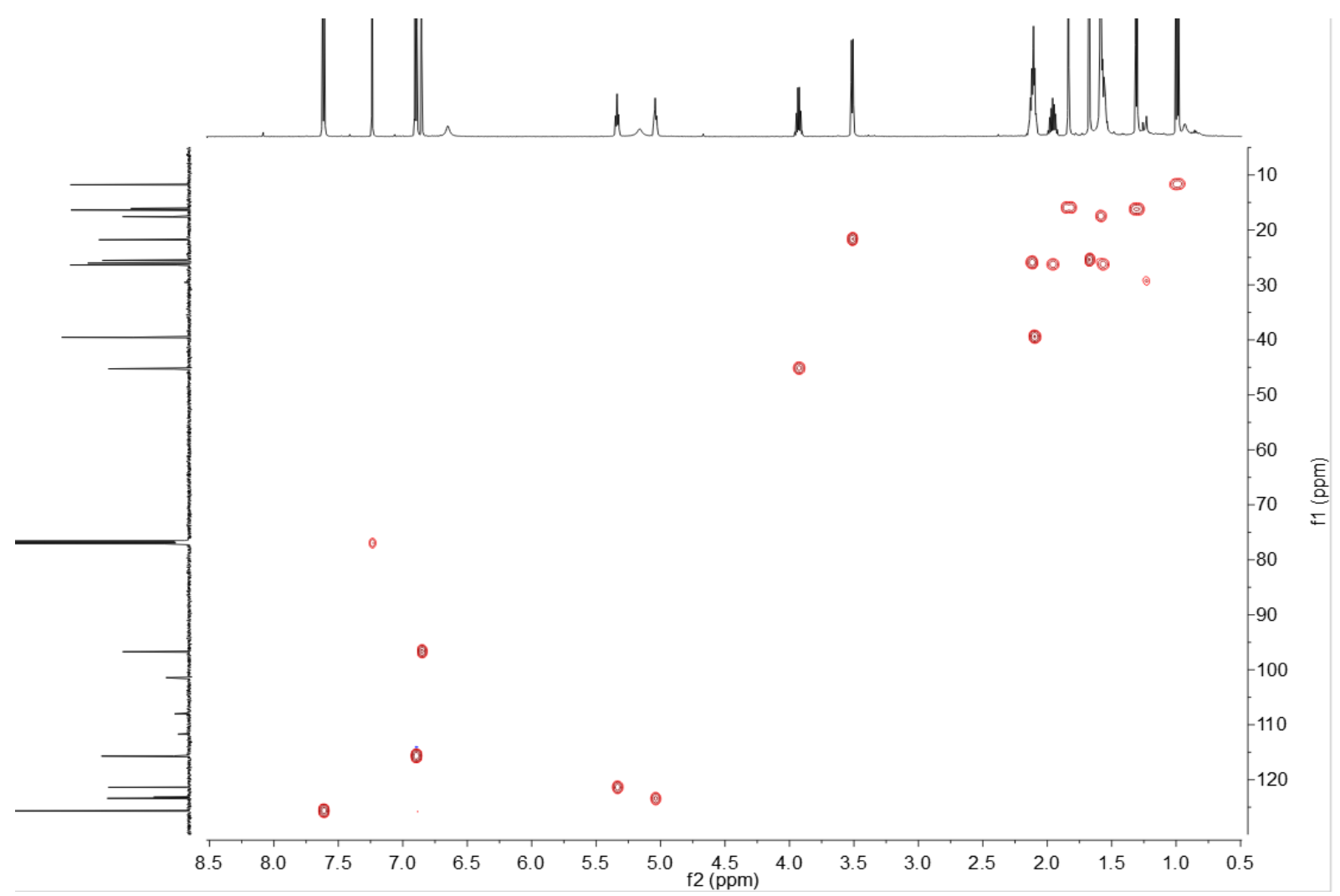

Figure S27. HSQC spectrum of 4.

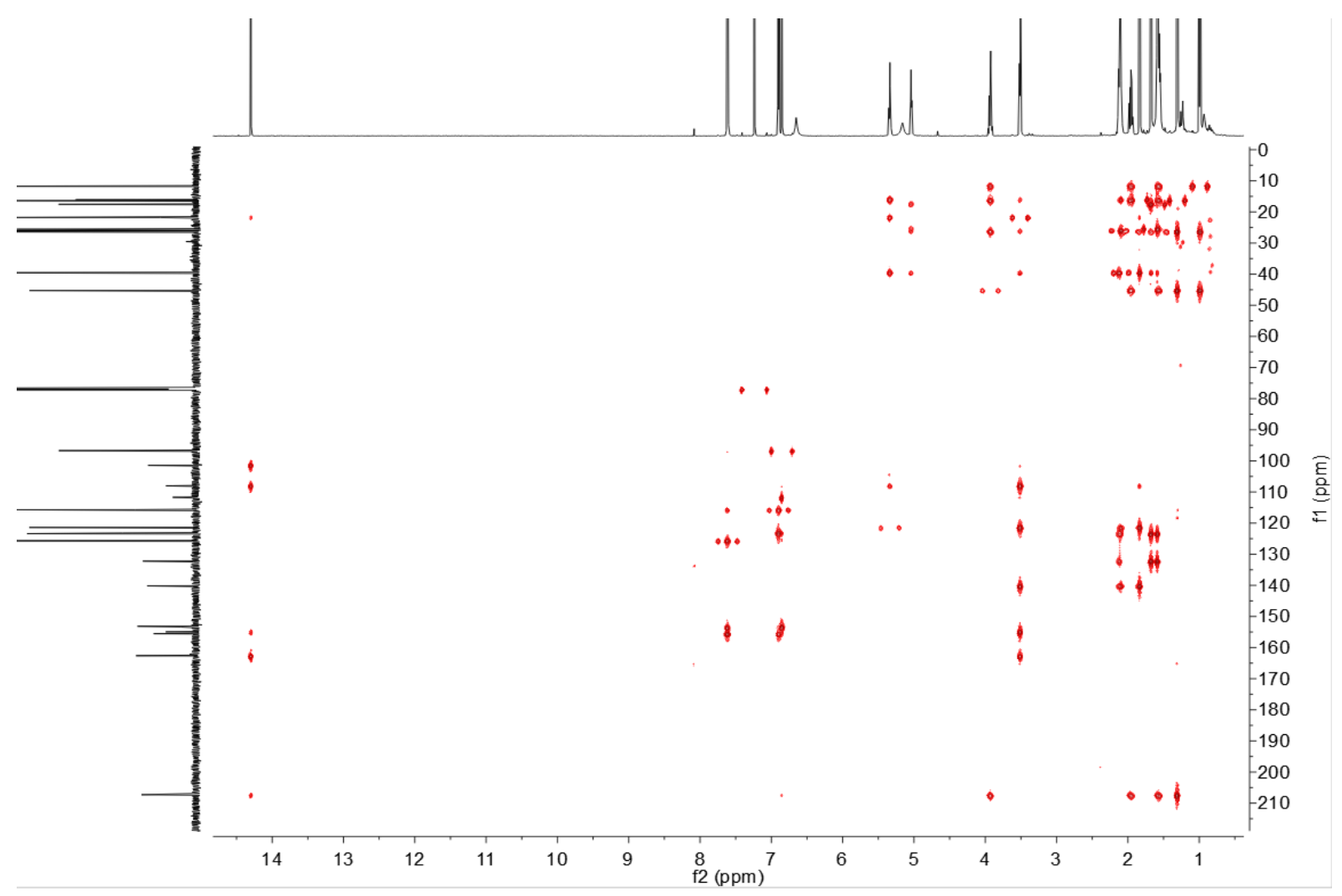

Figure S28. HMBC spectrum of 4. 


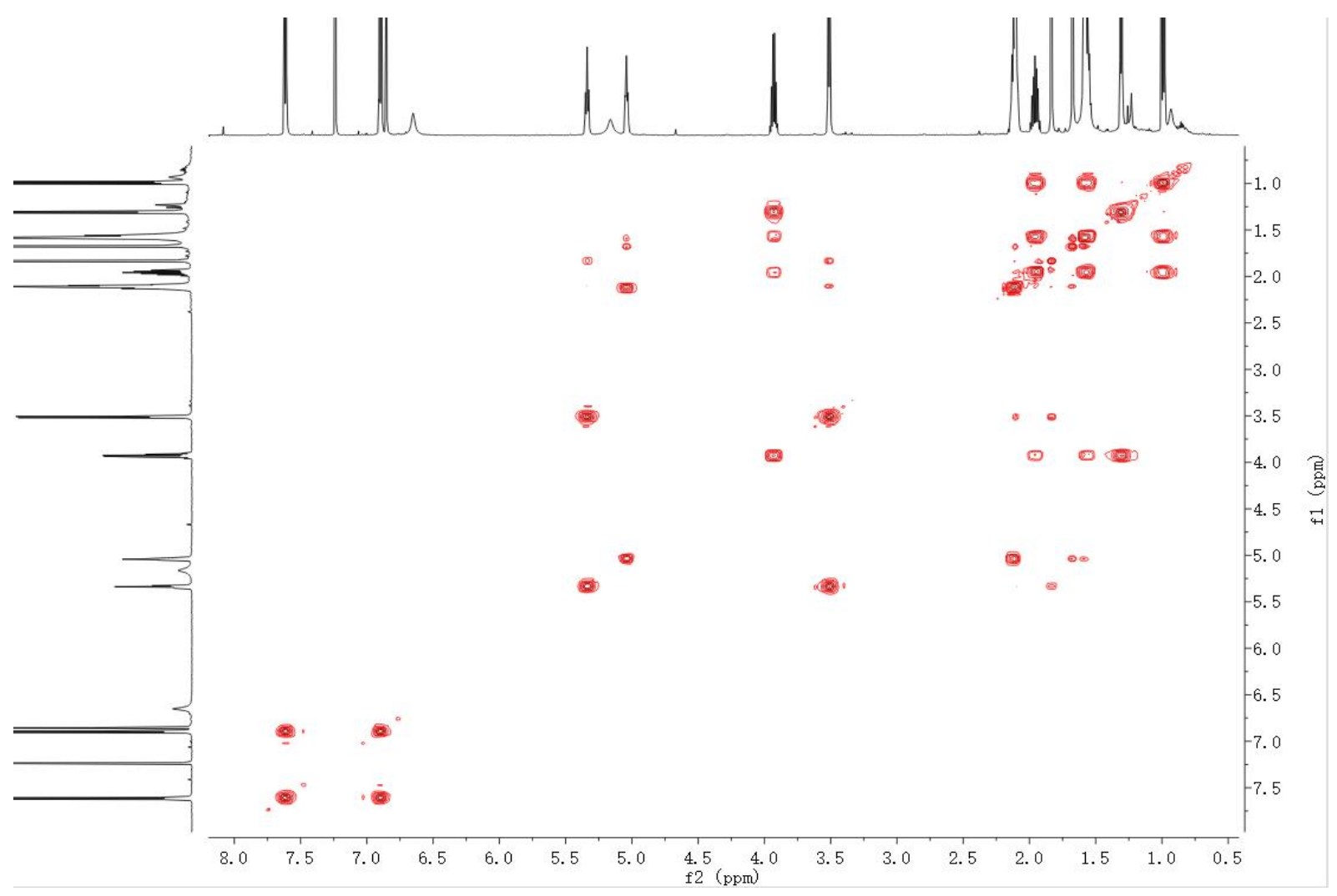

Figure S29. ${ }^{1} \mathrm{H}-{ }^{1} \mathrm{H}$ COSY spectrum of 4.

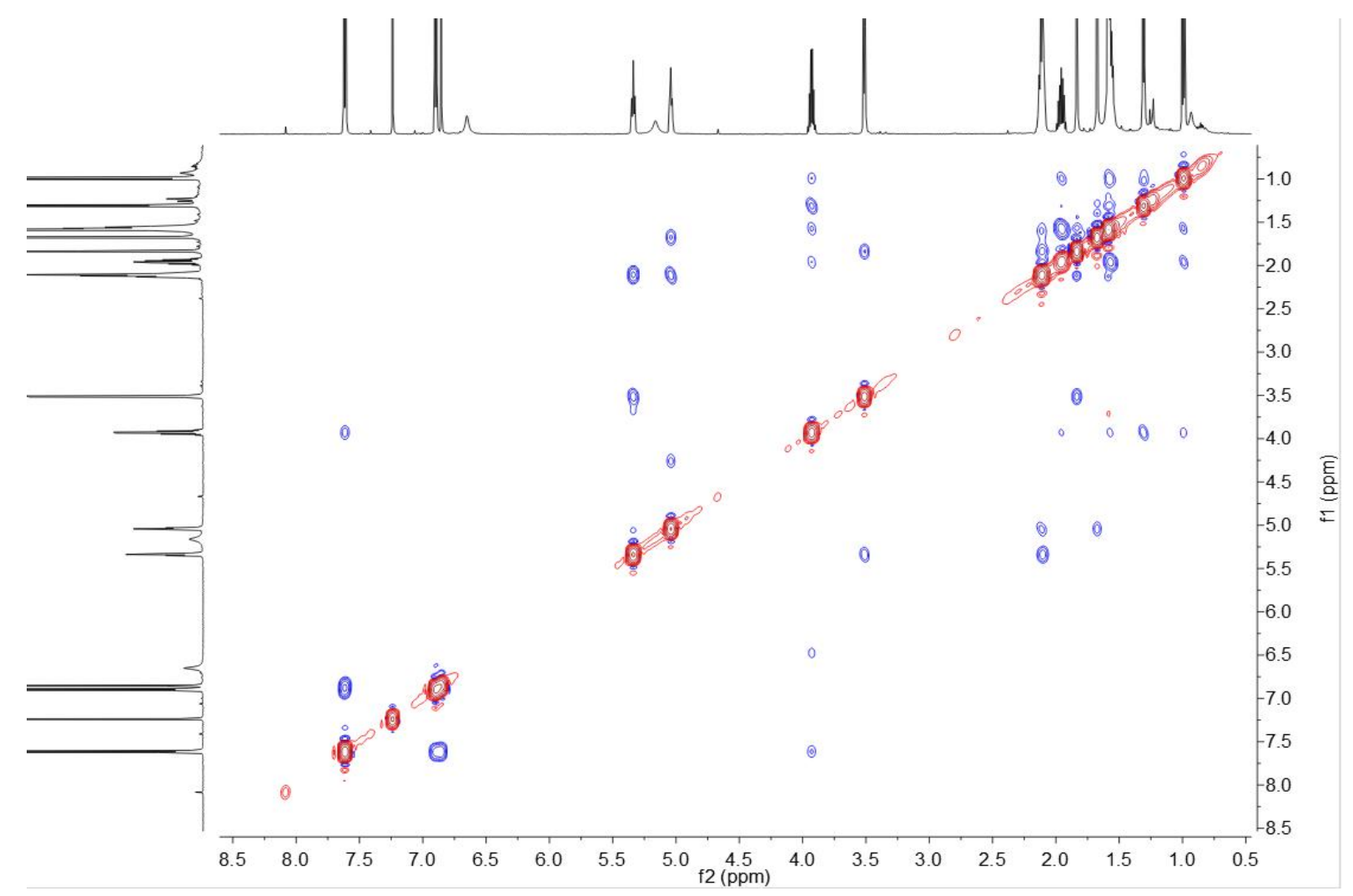

Figure S30. ROESY spectrum of 4. 


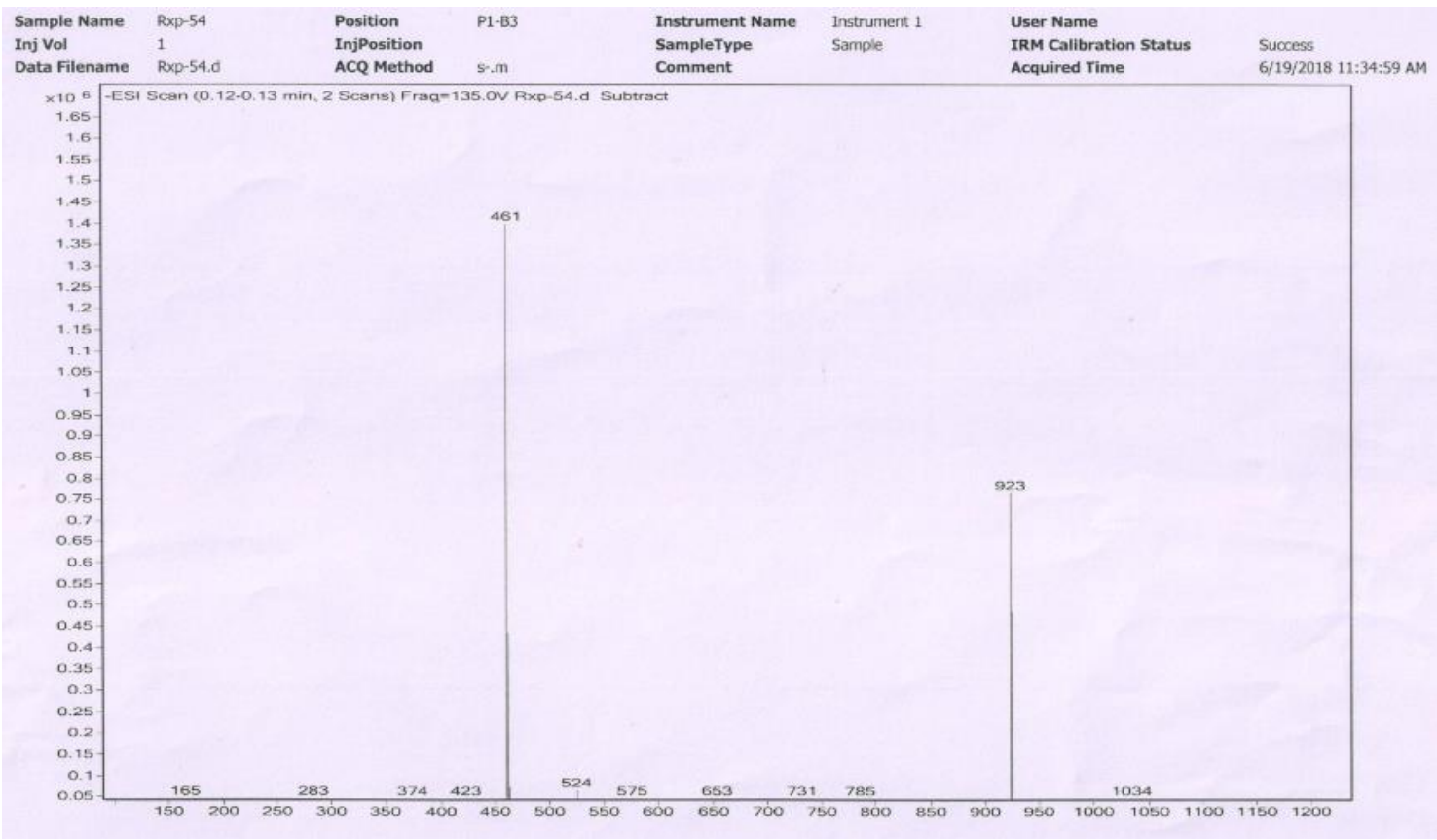

Figure S31. ESI-MS spectrum of 4. 


\section{Qualitative Analysis Report}

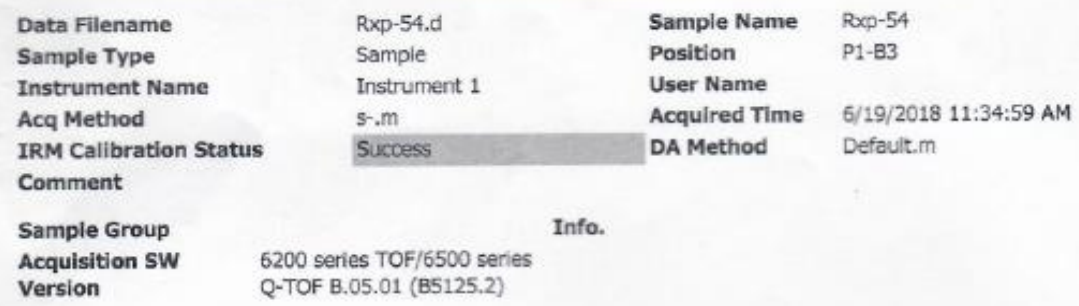

\section{User Spectra}

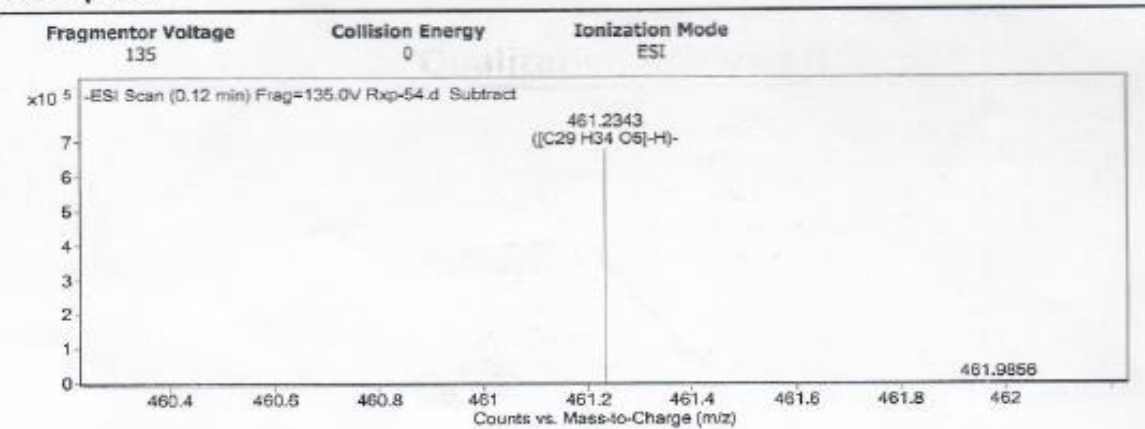

Peak List
\begin{tabular}{|l|r|l|l|l|}
\hline $\mathrm{m} / z$ & $\mathrm{z}$ & Abund & Formula & Ion \\
\hline 461.2343 & 1 & 678061.13 & $\mathrm{C} 29 \mathrm{H} 34$ O5 & $(\mathrm{M}-\mathrm{H})$ - \\
\hline 462.2378 & 1 & 206599.98 & $\mathrm{C} 29 \mathrm{H} 34$ O5 & $(\mathrm{M}-\mathrm{H})$ - \\
\hline 463.2405 & 1 & 37486.55 & $\mathrm{C} 29 \mathrm{H} 34$ O5 & $(\mathrm{M}-\mathrm{H})-$ \\
\hline 524.2297 & 1 & 46824.64 & & \\
\hline 525.2329 & 1 & 13660.52 & & \\
\hline 575.2267 & 1 & 14592.47 & & \\
\hline 923.4754 & 1 & 274865.97 & & \\
\hline 924.4789 & 1 & 179375.77 & & \\
\hline 925.481 & 1 & 58526.83 & & \\
\hline 926.4838 & 1 & 12509.33 & & \\
\hline Formula Cal &
\end{tabular}

\begin{tabular}{l|c|c|c}
926.4838 & 1 & 12509.33 \\
\hline Formula Calculator Element Lmits
\end{tabular}

\begin{tabular}{|l|r|c|}
\hline Element & Min & Max \\
\hline C & 3 & 60 \\
\hline H & 0 & 240 \\
\hline O & 0 & 10 \\
\hline
\end{tabular}

\begin{tabular}{l|r|r}
\hline O & 0 & 10 \\
\hline Formula Calculator Results
\end{tabular}

\begin{tabular}{|l|r|r|r|r|r|r|}
\hline Formula & CalculatedMass & CalculatedMz & Mz & Diff. (mDa) & Diff. (ppm) & DBE \\
\hline C29 H34 O5 & 462.2406 & 461.2333 & 461.2343 & -1.00 & -2.17 & 13.0000 \\
\hline
\end{tabular}

-... End Of Report -.-

Figure S32. HR-ESIMS spectrum of 4. 


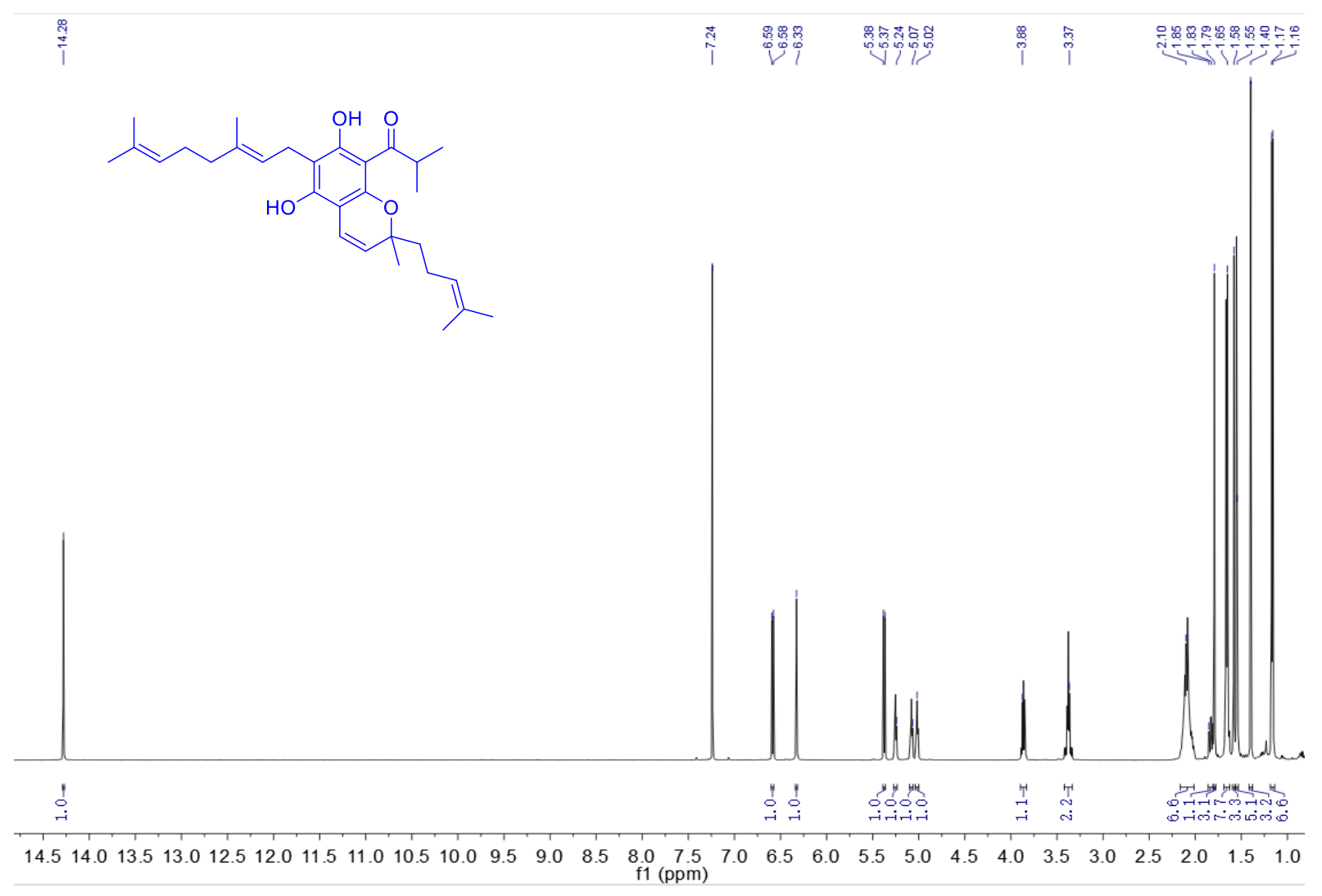

Figure S33. ${ }^{1} \mathrm{H}$ (in $\mathrm{CDCl}_{3}$ ) spectrum of 5 .
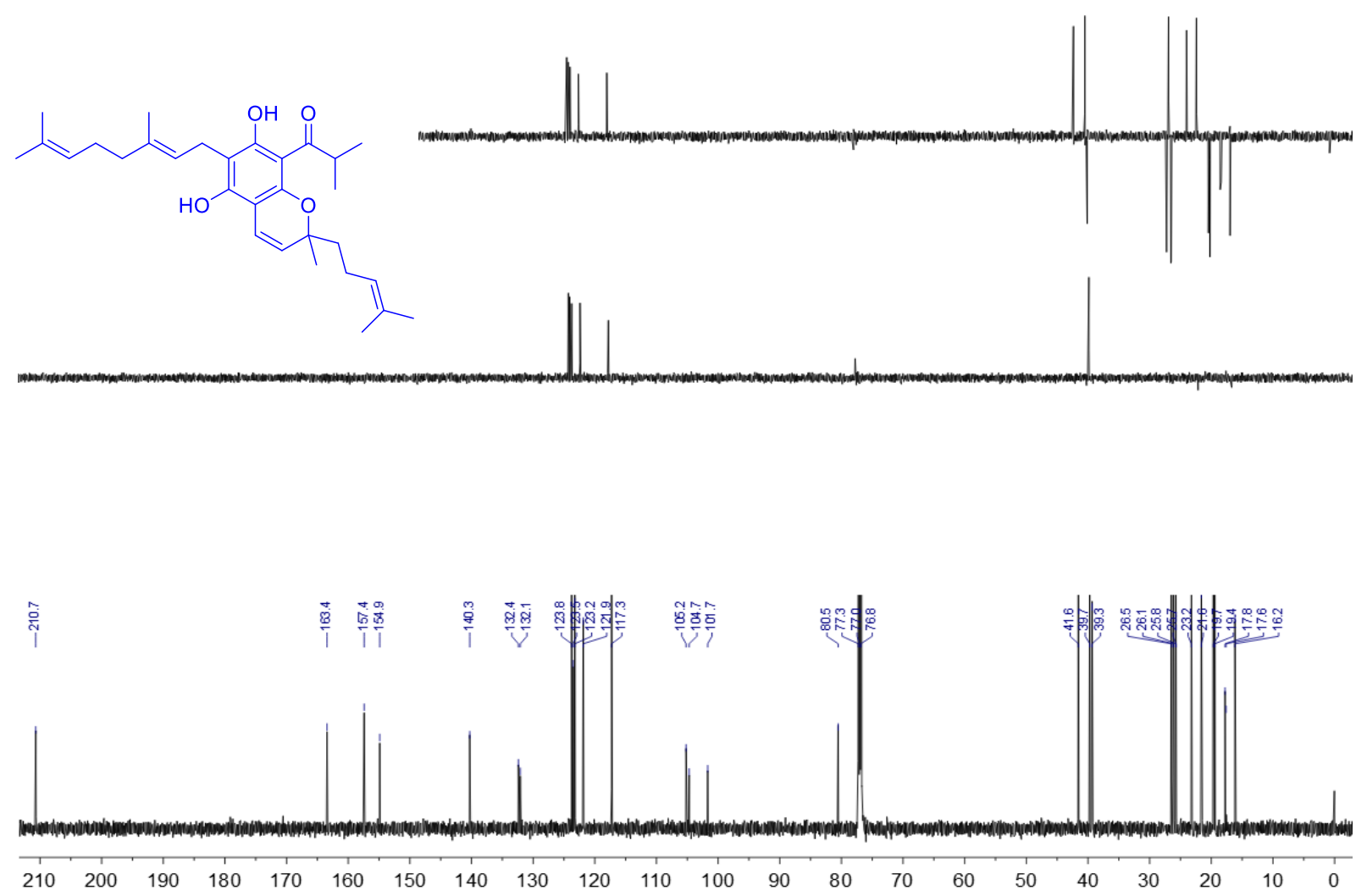

Figure S34. ${ }^{13} \mathrm{C}$ and DEPT (in $\mathrm{CDCl}_{3}$ ) spectrum of $\mathbf{5}$. 


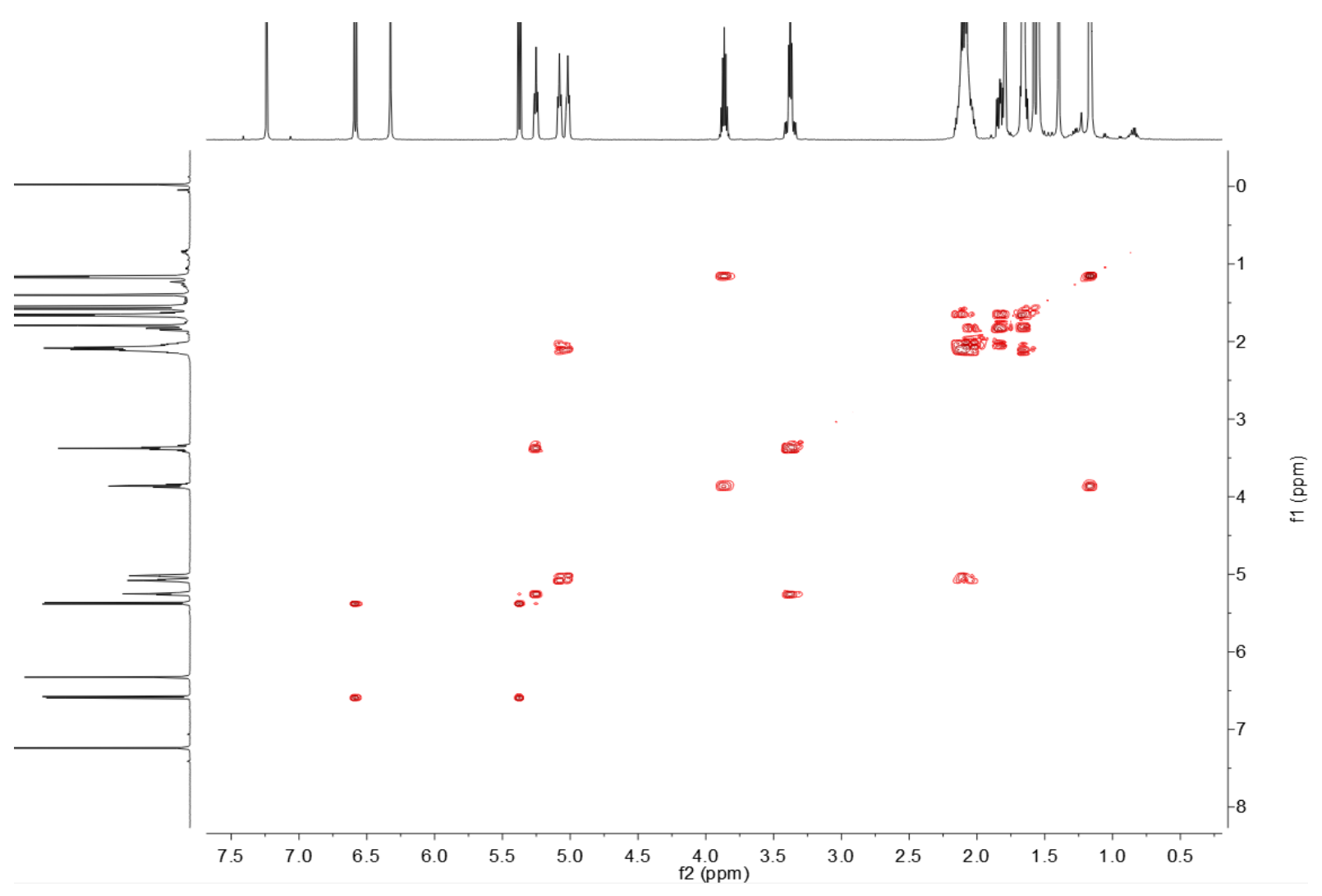

Figure S35. HSQC spectrum of 5.

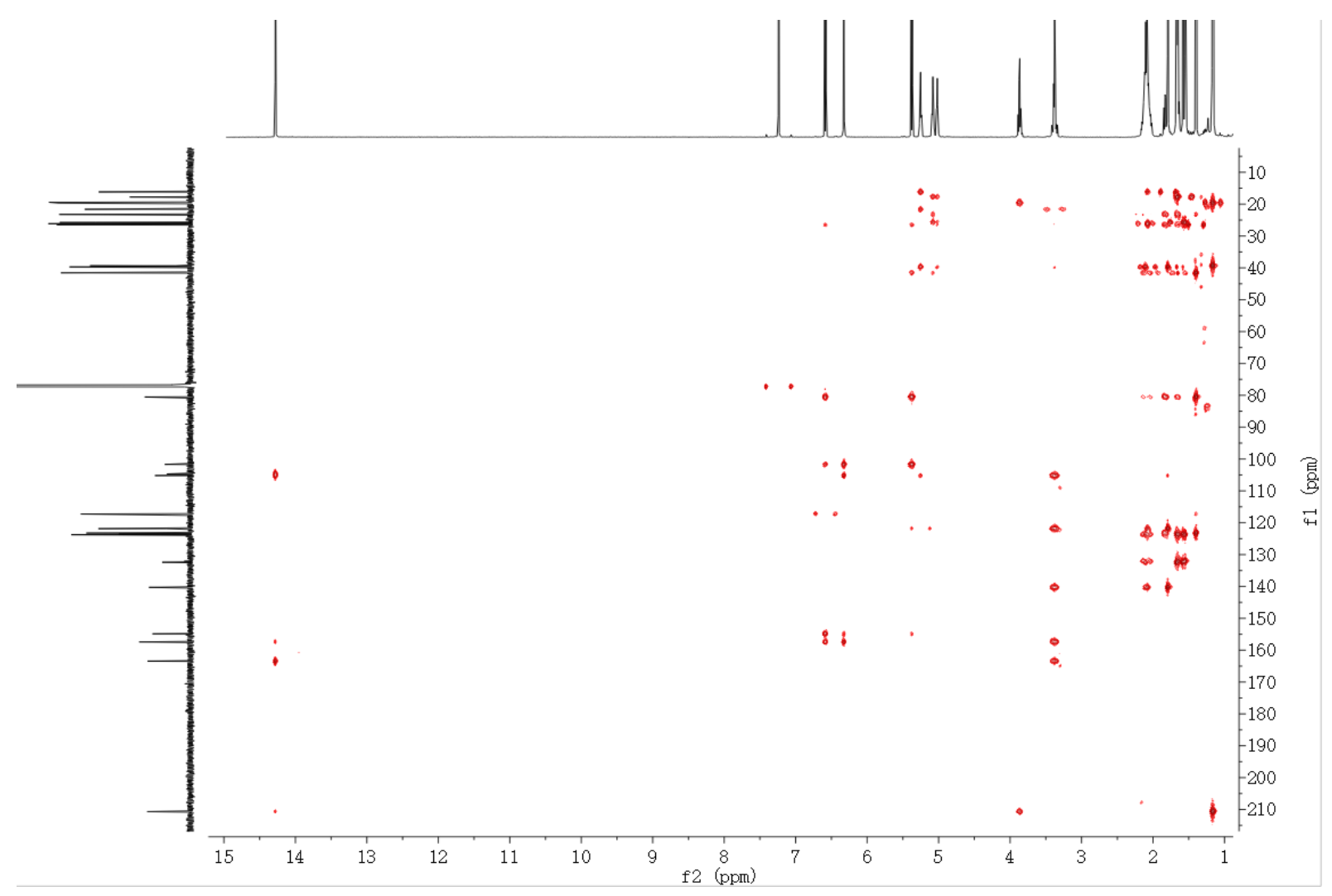

Figure S36. HMBC spectrum of 5. 


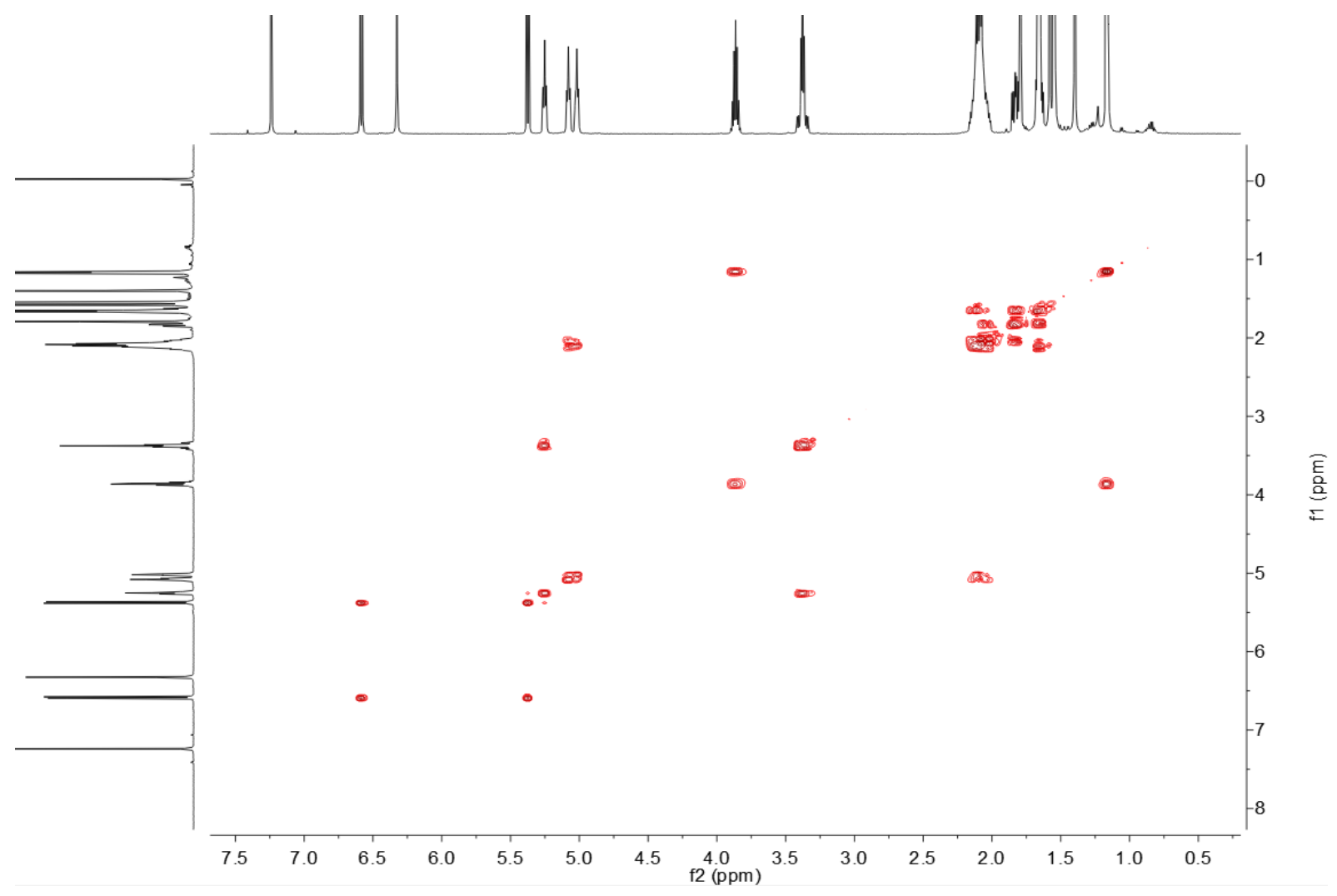

Figure S37. ${ }^{1} \mathrm{H}-{ }^{1} \mathrm{H}$ COSY spectrum of 5.

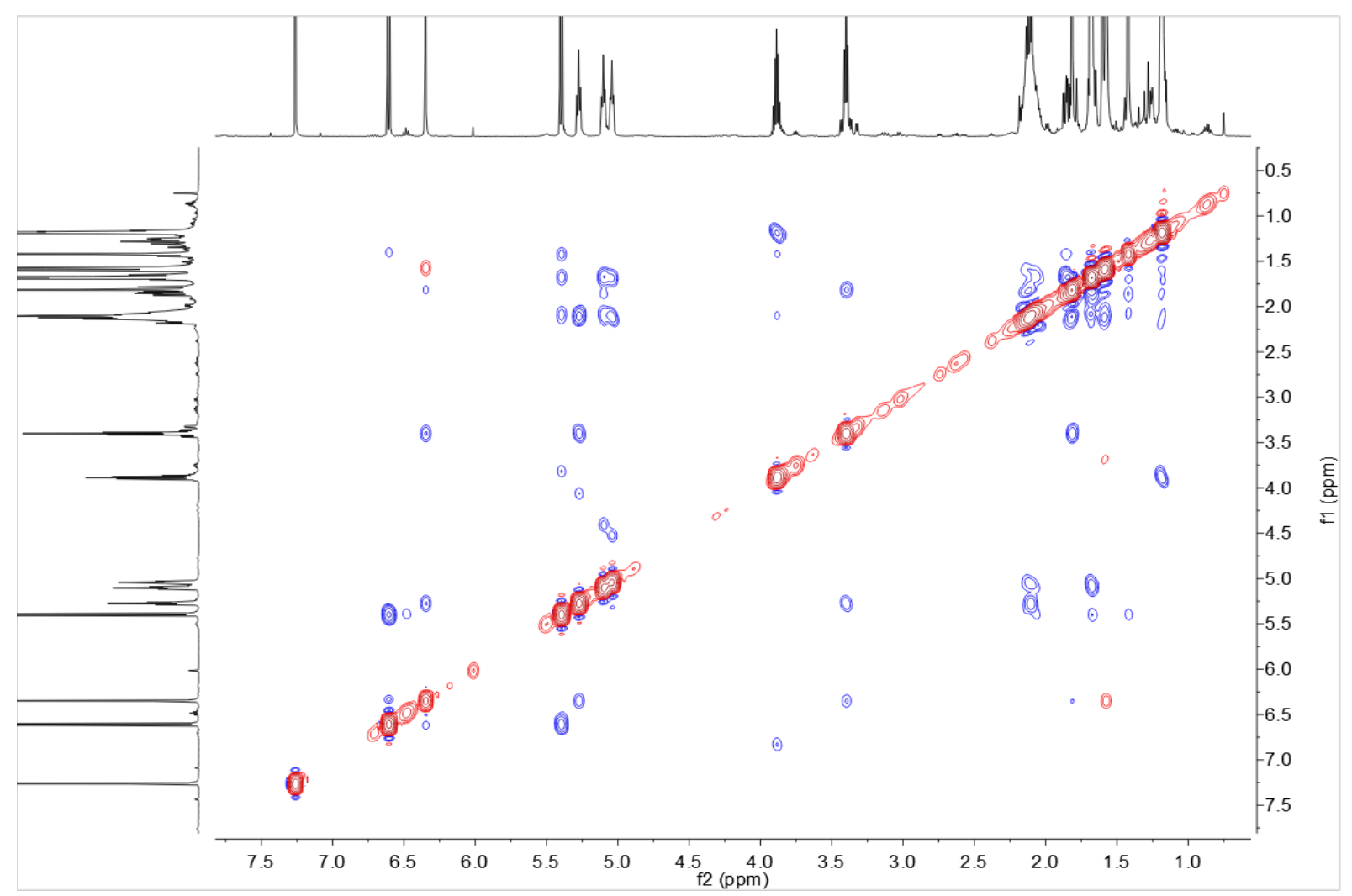

Figure S38. ROESY spectrum of 5. 


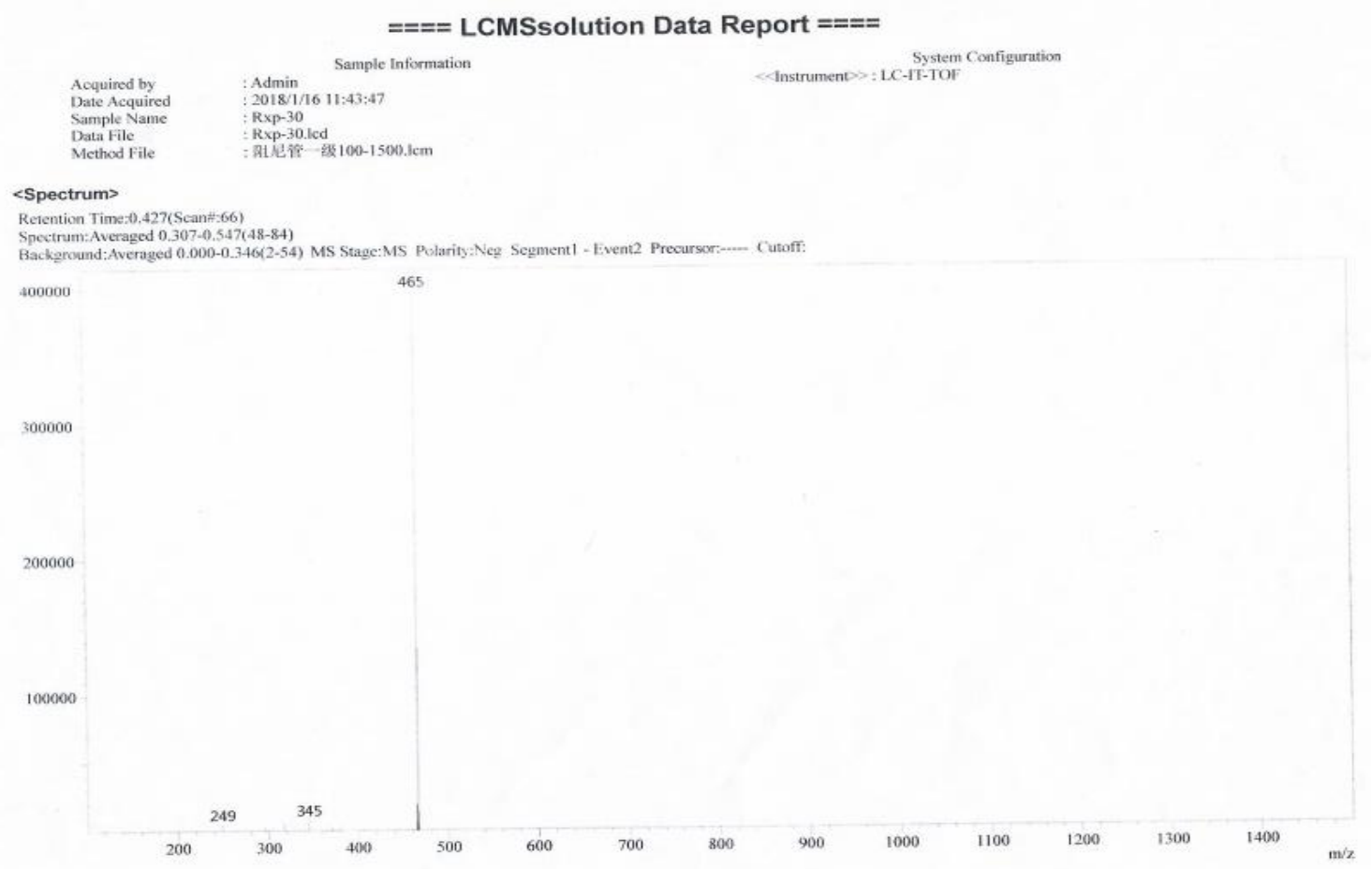

Figure S39. TOF-MS spectrum of 5. 
Data File: E:IDATAI201810125IRxp-30.Icd

\begin{tabular}{|c|c|c|c|c|c|c|c|c|c|c|c|c|c|c|c|c|}
\hline Elmt & Val. & Min & $\operatorname{Max}$ & Elmt & Val. & Min & Max & Elmt & Val. & Min & Max & Elmt & Val. & Min & Max & Use Adduct \\
\hline $\mathrm{H}$ & 1 & 0 & 200 & 0 & 2 & 0 & 50 & $\mathrm{Si}$ & 4 & 0 & 0 & $\mathrm{Br}$ & 1 & 0 & 0 & H \\
\hline C & 4 & 0 & 100 & $\mathrm{~F}$ & 1 & 0 & 0 & S & 2 & 0 & 0 & 1 & 3 & 0 & 0 & \\
\hline $\mathrm{N}$ & 3 & 0 & 0 & $\mathrm{Na}$ & 1 & 0 & 0 & $\mathrm{Cl}$ & 1 & 0 & 0 & & & & & \\
\hline Error $\mathrm{N}$ & $\begin{array}{r}\text { argin } \\
\text { HC } \\
\text { ax Iso } \\
\text { Iso }\end{array}$ & $\begin{array}{l}\text { atio: } \\
\text { pes: } \\
(\%) \text { : }\end{array}$ & $\begin{array}{l}\text { unlimite } \\
\text { all } \\
75.00\end{array}$ & & & $\begin{array}{r}\text { D } \\
\text { Ap } \\
\text { Isotc } \\
\text { MSn Le }\end{array}$ & $\begin{array}{l}\text { BE Ra } \\
\text { oly N F } \\
\text { ope RI } \\
\text { ogic M }\end{array}$ & $\begin{array}{l}\text { e: }-2.0 \\
\text { e: yes } \\
\text { o): } 1.00 \\
\text { e: ANL }\end{array}$ & -100.0 & & & $\begin{array}{l}\text { Electro } \\
\text { Use MS } \\
\text { Isoto } \\
\text { Max F }\end{array}$ & $\begin{array}{l}n \text { lons: } \\
\text { nn Info: } \\
\text { e Res: } \\
\text { esults: }\end{array}$ & $\begin{array}{l}\text { both } \\
\text { yes } \\
10000 \\
10\end{array}$ & & \\
\hline
\end{tabular}

Event\#: $2 \mathrm{MS}(\mathrm{E}-)$ Ret. Time : $0.347 \rightarrow 0.587$ Scan\# : $54 \rightarrow 90$

465.3010

$8.500 \mathrm{e} 5$

$8.000 \mathrm{e} 5$

$7.500 \mathrm{e} 5$

$7.000 \mathrm{e} 5$

$6.500 \mathrm{e} 5$

$6.000 \mathrm{e} 5$

$5.500 \mathrm{e} 5$

$5.000 \mathrm{e} 5$

$4.500 \mathrm{e} 5$

$4.000 \mathrm{e} 5$

$3.500 \mathrm{e} 5$

$\begin{array}{llllllllll}465.275 & 465.280 & 465.285 & 465.290 & 465.295 & 465.300 & 465.305 & 465.310 & 465.315 & 465.320\end{array}$

Measured region for $465.3010 \mathrm{~m} / \mathrm{z}$

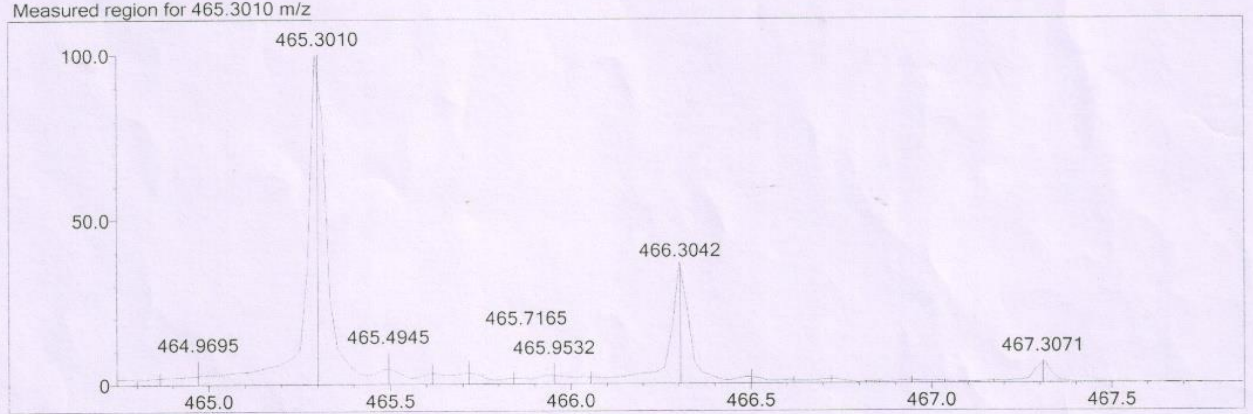

$\mathrm{C} 30 \mathrm{H} 42 \mathrm{O} 4$ [M-H] - : Predicted region for $465.3010 \mathrm{~m} / \mathrm{z}$

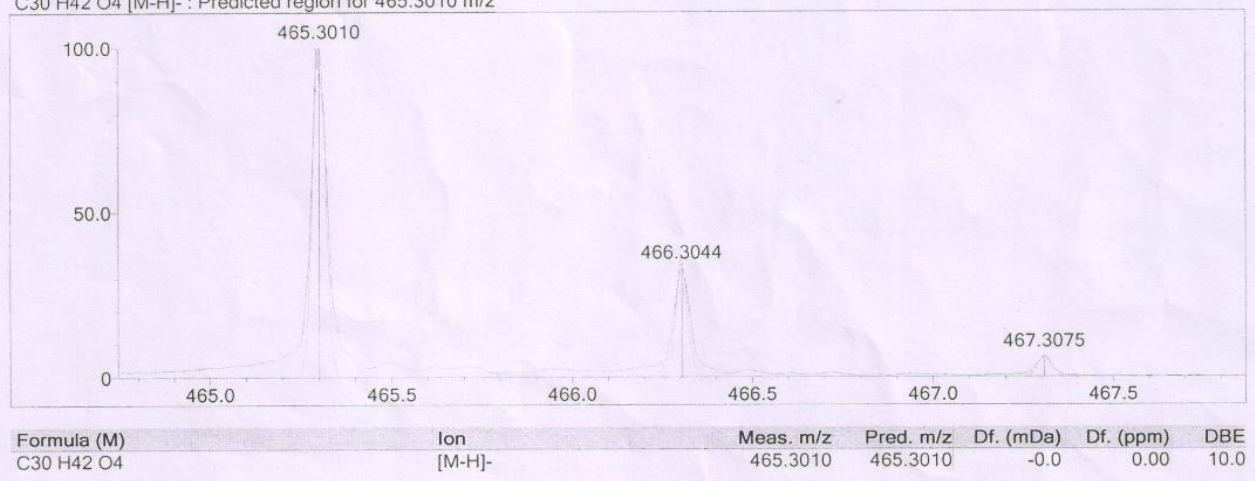

Figure S40. HR-EIMS spectrum of $\mathbf{5}$. 
<smiles>Cc1c(O)c2c(c(C(=O)CCc3ccccc3)c1O)OC(C)(C)C=C2</smiles>

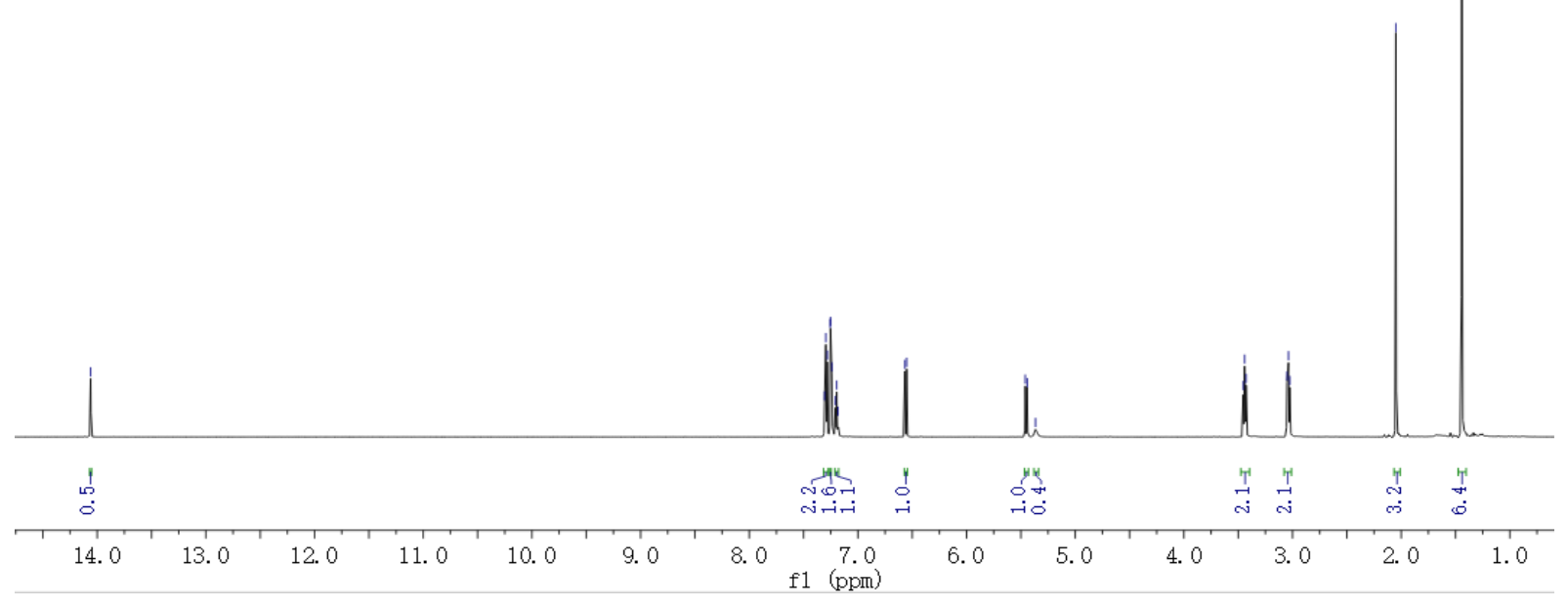

Figure S41. ${ }^{1} \mathrm{H}$ (in $\mathrm{CDCl}_{3}$ ) spectrum of 6 .
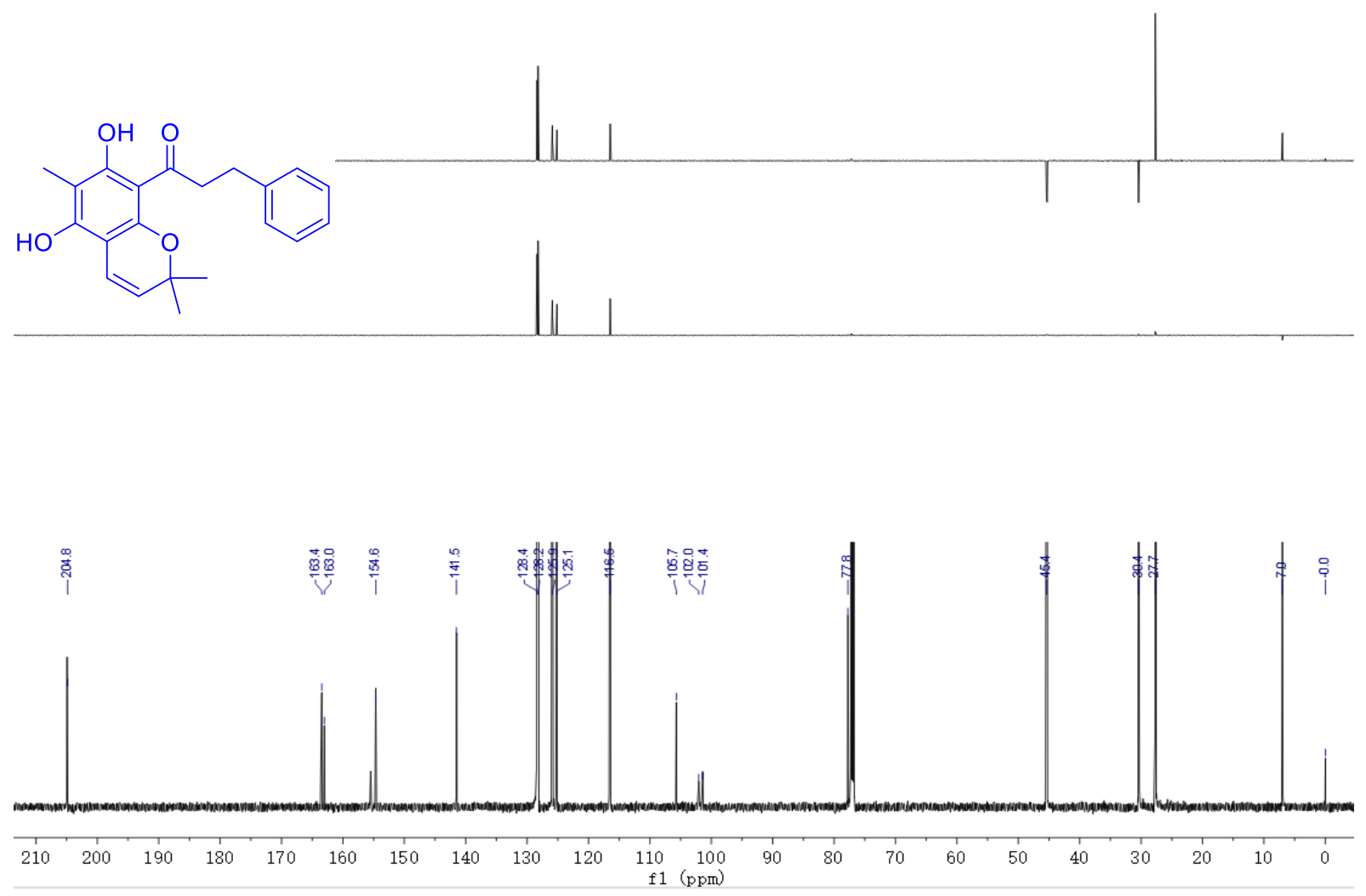

Figure $\mathbf{S 4 2 .}{ }^{13} \mathrm{C}$ and DEPT (in $\mathrm{CDCl}_{3}$ ) spectrum of 6. 


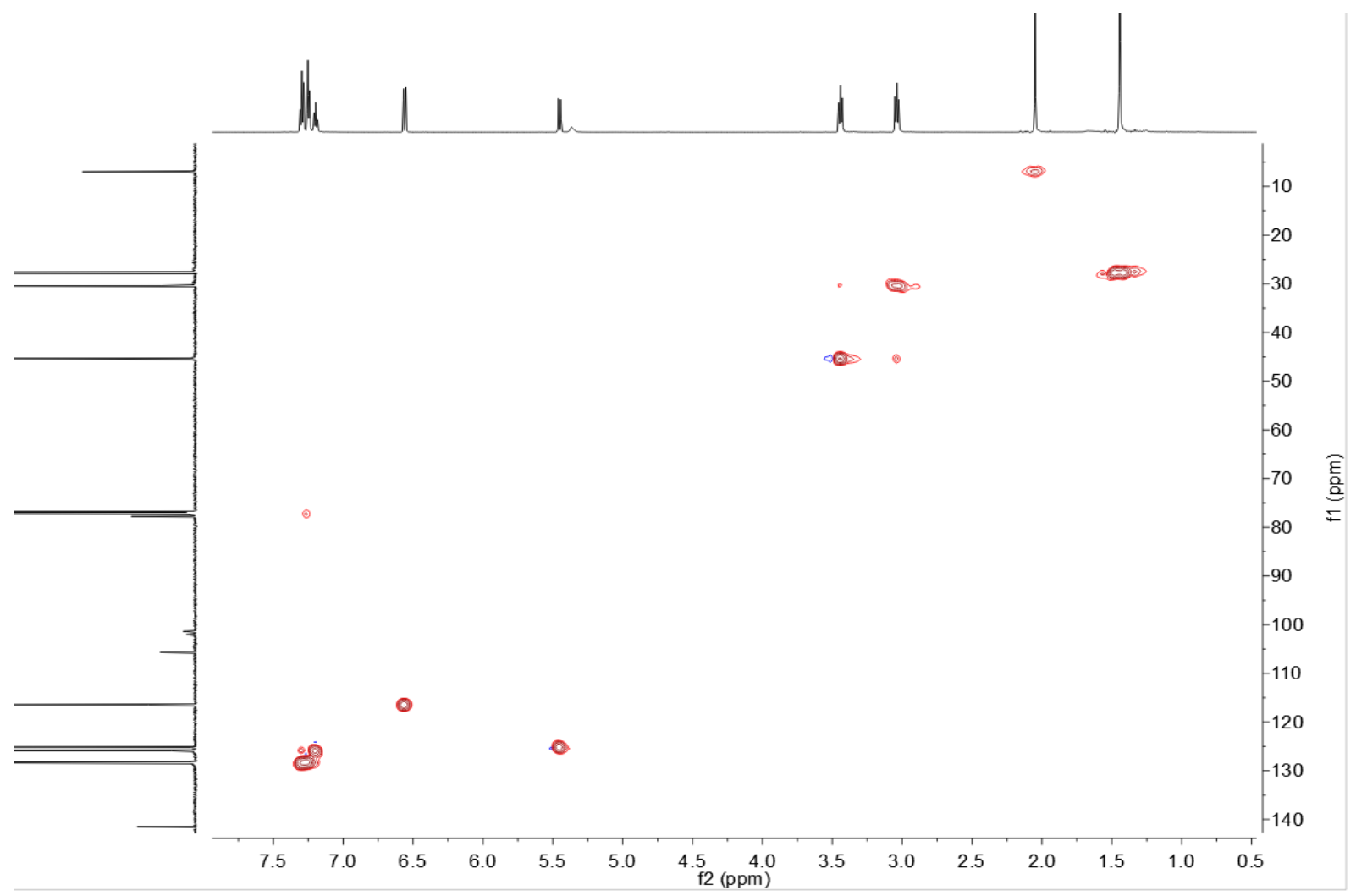

Figure S43. HSQC spectrum of 6.

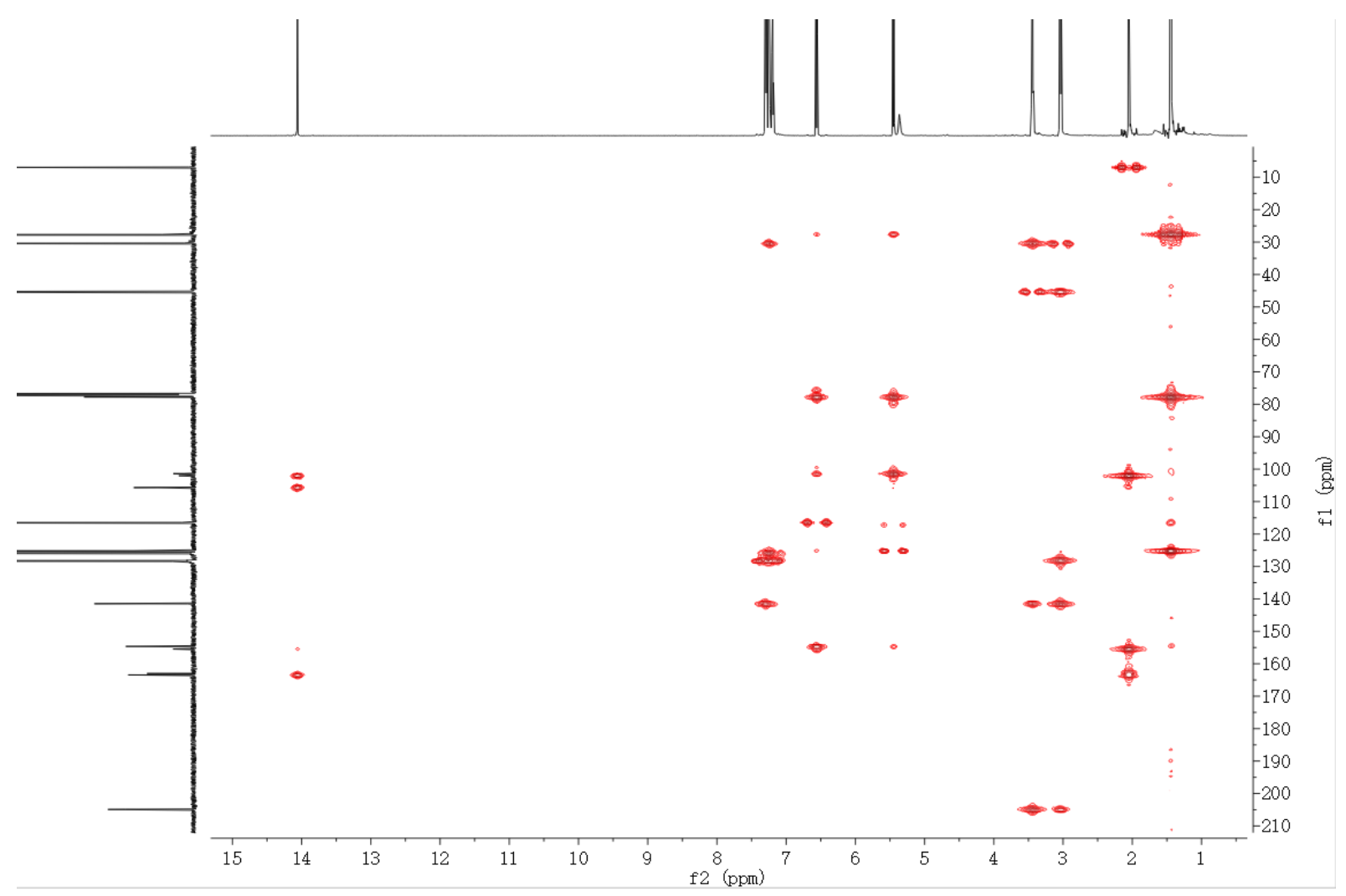

Figure S44. HMBC spectrum of 6. 


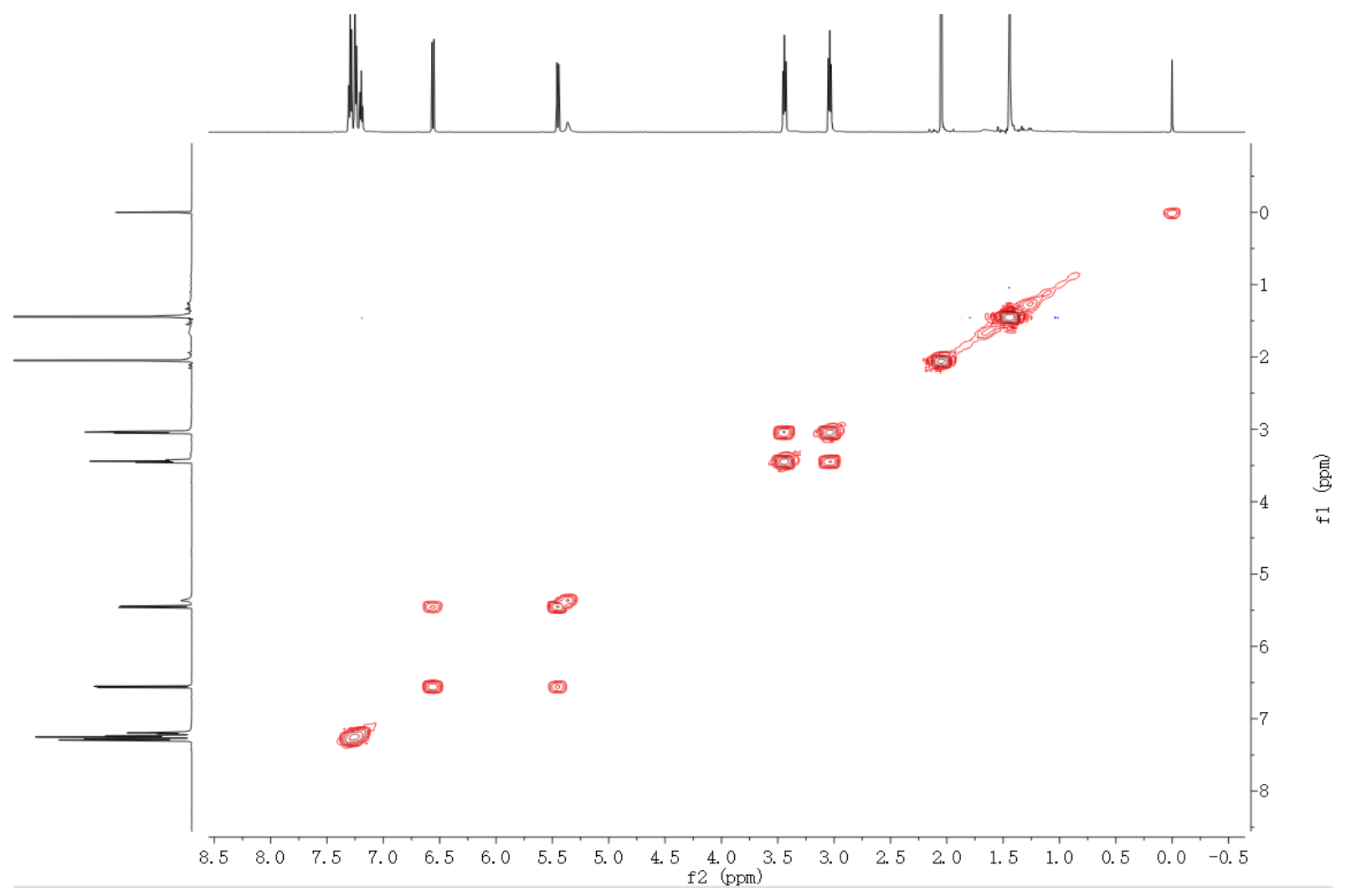

Figure S45. ${ }^{1} \mathrm{H}-{ }^{1} \mathrm{H}$ COSY spectrum of 6 .

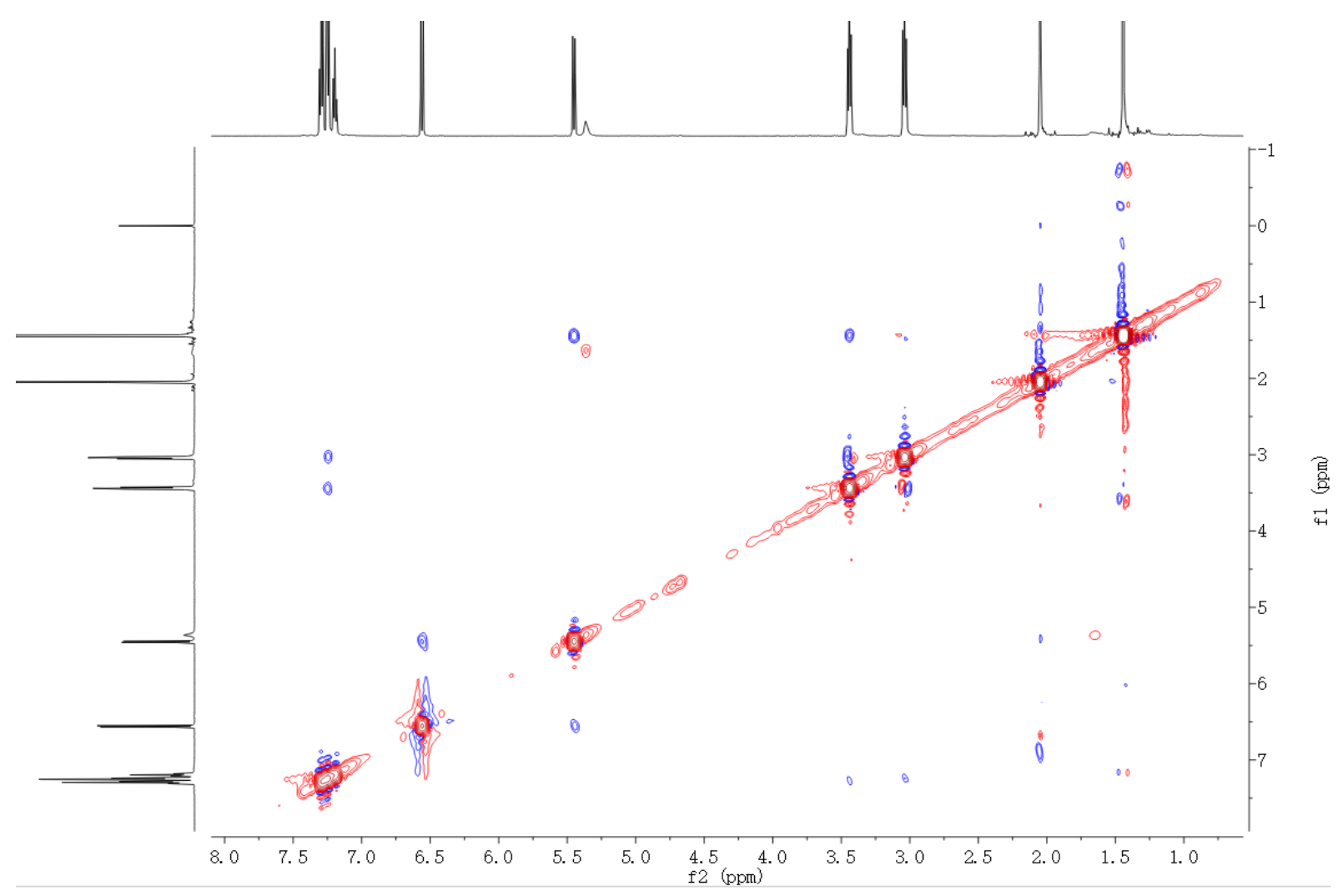

Figure S46. ROESY spectrum of 6. 


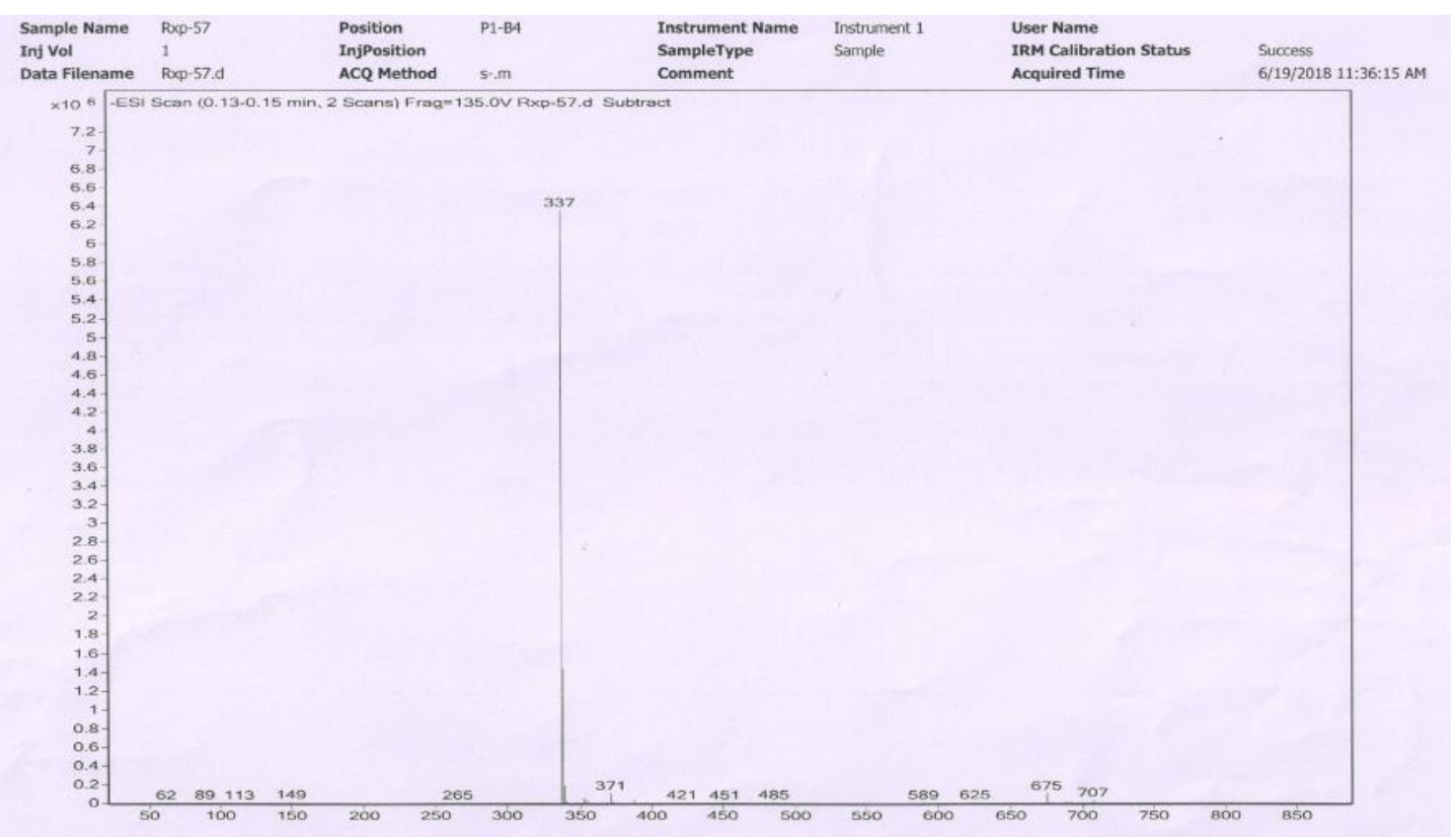

Figure S47. ESI-MS spectrum of 6 . 


\section{Qualitative Analysis Report}

\begin{tabular}{|c|c|c|c|}
\hline Data Filename & Rxp-57.d & Sample Name & $R \times p-57$ \\
\hline Sample Type & Sample & Position & $P_{1}-84$ \\
\hline Instrument Name & Instrument 1 & User Name & \\
\hline Acq Method & s-m & Acquired Time & $6 / 19 / 2018$ 11:36:15 AM \\
\hline IRM Calibration Status & Success & DA Method & Defaust.m \\
\hline Comment & & & \\
\hline Sample Group & & & \\
\hline $\begin{array}{l}\text { Acquisition SW } \\
\text { Version }\end{array}$ & $\begin{array}{l}\text { ies TOF/6500 series } \\
.05 .01(85125.2)\end{array}$ & & \\
\hline
\end{tabular}

User Spectra
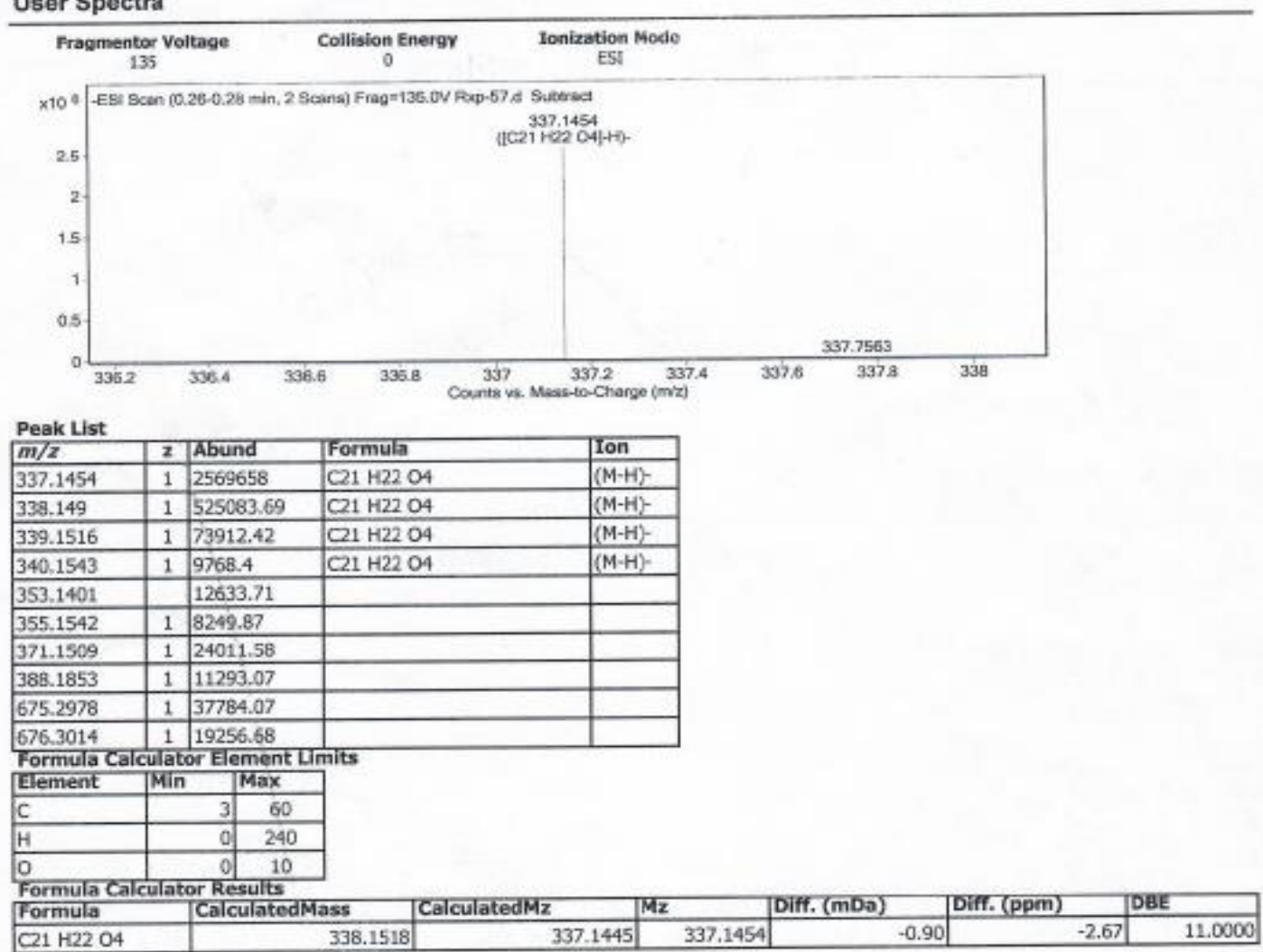

- End of Report --.

Figure S48. HR-ESIMS spectrum of 6. 